\title{
The overwintering of Antarctic krill, Euphausia superba, from an ecophysiological perspective
}

\author{
Bettina Meyer
}

Received: 22 June 2011 / Revised: 13 October 2011 / Accepted: 13 October 2011 / Published online: 15 November 2011

(C) The Author(s) 2011. This article is published with open access at Springerlink.com

\begin{abstract}
A major aim of this review is to determine which physiological functions are adopted by adults and larvae to survive the winter season with low food supply and their relative importance. A second aim is to clarify the extent to which seasonal variation in larval and adult krill physiology is mediated by environmental factors with a strong seasonality, such as food supply or day light. Experimental studies on adult krill have demonstrated that specific physiological adaptations during autumn and winter, such as reduced metabolic rates and feeding activity, are not caused simply by the scarcity of food, as was previously assumed. These adaptations appear to be influenced by the local light regime. The physiological functions that larval krill adopt during winter (reduced metabolism, delayed development, lipid utilisation, and variable growth rates) are, in contrast to the adults, under direct control by the available food supply. During winter, the adults often seem to have little association with sea ice (at least until early spring). The larvae, however, feed within sea ice but mainly on the grazers of the ice algal community rather than on the algae themselves. In this respect, a miss-match in timing of the occurrence of the last phytoplankton blooms in autumn and the start of the sea ice formation, as has been increasingly observed in the west Antarctic Peninsula (WAP) region, will impact larval krill development during winter in terms of food supply and consequently the krill stock in this region.
\end{abstract}

B. Meyer $(\bowtie)$

Alfred Wegener Institute for Polar and Marine Research,

Scientific Division Polar Biological Oceanography,

Am Handelshafen 12, 27570 Bremerhaven, Germany

e-mail: Bettina.Meyer@awi.de
Keywords Adult krill · Larval krill · Overwintering · Climate change

\section{Introduction}

Antarctic krill, Euphausia superba, (hereafter "krill") shape the structure of the marine Antarctic ecosystem, due to their central position within the Southern Ocean food web as prey of a wide range of higher trophic predators and as effective grazers on autotrophic and heterotrophic plankton organisms. In addition, an important role for krill in biogeochemical cycles such as carbon export and iron-recycling has been identified (Le-Fevre et al. 1998; Tovar-Sanchez et al. 2007). Despite 80 years of krill research, the mechanistic understanding of how krill respond to environmental changes remains unclear because within the time span from 1920 to early 1980s, krill research was mainly driven by commercial interests. When systematic krill research started in the early twentieth century, it was driven by the intense whaling activity in Antarctic waters, culminating in a bonanza period between 1920 and 1930. A prerequisite for estimating distribution and movement of the whales themselves was to understand the distribution and movement of the whales' food-krill—and what was controlling them in particular (Marr 1962). This "ecosystem" approach gave birth to the "Discovery Expeditions". The comprehensive data set derived from these expeditions around Antarctica and mainly published in the Discovery Reports laid the foundation for today's knowledge on the distribution and life cycle of krill. During the 1950s, the whaling industry in the Southern Ocean collapsed and hence the demand in krill research. In the beginning of the 1970s, a revival of marine Antarctic research started. At this time, many traditional fishing grounds were either fully or over-exploited so that 
Table 1 Summary of major krill programmes from 1926 to 2009

\begin{tabular}{|c|c|}
\hline Programmes and time span & Topic addressed \\
\hline $\begin{array}{l}\text { Discovery expeditions } \\
\quad(1926-1939)\end{array}$ & $\begin{array}{l}\text { Large-scale exploration } \\
\text { Circumpolar distribution and the life cycle of krill in the } \\
\text { Southern Ocean }\end{array}$ \\
\hline BIOMASS (1980s-early 1990s) & $\begin{array}{l}\text { Large-scale exploration } \\
\text { Distribution, abundance, stock assessment in selected ocean areas }\end{array}$ \\
\hline AMERIEZ (1983-1988) & Process-oriented studies \\
\hline EPOS (1988-1989) & The integral part of seasonal pack ice in the life history of krill \\
\hline SO-GLOBEC (1999-2009) & $\begin{array}{l}\text { The distribution of krill and its developmental stages in relation } \\
\text { to sea ice } \\
\text { The linkage between physical and biological factors that promote } \\
\text { krill growth, reproduction, recruitment, and survival throughout } \\
\text { the year }\end{array}$ \\
\hline CCAMLR 2000 Survey & $\begin{array}{l}\text { A first large-scale synoptic biomass and distribution survey in the } \\
\text { Atlantic Sector using strict method protocols }\end{array}$ \\
\hline
\end{tabular}

alternative unexploited and freely accessible marine resources of high abundance and productivity had to be found. At the same time, the 200-nm economic zone had been introduced by many countries which further increased the pressure to search for new fishing grounds. A significant commercial krill fishery started, and ever since this has been the largest in the Southern Ocean in terms of tonnage caught. However, a problem at this time was the wide range of estimates of krill stocks, which varied from 23 to 1,350 million tonnes (Everson 1977). Therefore, krill research focused mainly on the abundance, distribution and a more accurate quantitative estimate of krill's biomass. In the 1980s, although this trend has continued, the focus was increasingly on krill in relation to its environment and more recently in which way physical and biological factors influence krill's annual cycle (Table 1). Within the process-oriented studies in the mid-to late 1980s (Table 1), various investigators were thinking about different concepts about overwintering. The importance of sea ice in the life cycle of krill, especially for over-winter survival, was set up by Smetacek et al. (1990). Some early work on larval krill illustrates the impact of sea ice habitat on larval fitness (Daly 1990; Ross and Quetin 1991). A long-term study by Siegel and Loeb (1995) showed correlation of recruitment and sea ice. Establishing the link of krill population dynamic with sea ice was among the major events in krill research. A range of correlation studies in the SW Atlantic between krill abundance and winter sea ice duration (Loeb et al. 1997; Atkinson et al. 2004) and seasonal sea ice dynamic (Ross et al. 2008) suggested that krill is vulnerable to environmental changes related to climate variability. While these studies make us aware of a changing trend in the ecosystem (e.g. increasing seawater temperature, timing of sea ice extent and retreat), they provide no explanation as to why the winter sea ice duration seems to be a critical factor in the population dynamic of krill. However, only this knowledge enables us to predict the response of krill to the ongoing environmental changes such as a declining sea ice extent in the WAP region.

Previous reports on krill overwintering relied on speculation, because of the paucity of data. During the period from beginning of the 1980s until mid-1990s, several studies were published, which strongly influenced the scientific view of how Antarctic krill survive winter and introduced the concept of the importance of winter sea ice extent for recruitment success (Table 2). Research revealed a suite of overwintering mechanisms of adult krill that provide considerable flexibility in their response to winter conditions. They were first summarised in Quetin and Ross (1991):

Non-feeding strategies:

- The reduction in metabolic rates (Kawaguchi et al. 1986; Quetin and Ross 1991; Torres et al. 1994a)

- The utilisation of stored body lipids (Quetin and Ross 1991; Hagen et al. 2001)

- Shrinkage in size and utilisation of body protein (Ikeda and Dixon 1982; Quetin and Ross 1991)

Utilisation of food sources other than phytoplankton in the water column:

- Zooplankton (Huntley et al. 1994)

- Seabed detritus (Kawaguchi et al. 1986)

- Ice algae (e.g. Hamner et al. 1983; Marschall 1988; Spiridonov 1992)

The relative importance of the proposed overwintering mechanisms was difficult to judge because they have been observed separately or together at different times and places. Until the end of the 1990s, the prevailing view was that the observed metabolic reduction and shrinkage of adult krill in winter are the result of the low food supply 
Table 2 Summary of studies which demonstrated the different strategies that krill could use to survive winter and the importance of winter sea ice extent for recruitment success

\begin{tabular}{|c|c|c|}
\hline \multicolumn{2}{|l|}{ Factors discussed } & \multirow{2}{*}{$\begin{array}{l}\text { References } \\
\text { Ikeda and Dixon (1982) }\end{array}$} \\
\hline Shrinkage & $\begin{array}{l}\text { From laboratory experiments, shrinkage in response to } \\
\text { starvation proposed as possible overwintering } \\
\text { mechanism for krill }\end{array}$ & \\
\hline Feeding on ice algae & $\begin{array}{l}\text { Investigated the ability of krill to feed on ice algae and } \\
\text { readdressed the question on how krill overwinter }\end{array}$ & Hamner et al. (1983) \\
\hline Benthic feeding & Showed evidence for benthic feeding by krill in winter & Kawaguchi et al. (1986) \\
\hline $\begin{array}{l}\text { Reduced feeding and metabolism, switching } \\
\text { food sources, lipid utilisation and shrinkage }\end{array}$ & $\begin{array}{l}\text { Outlined the first comprehensive view of krill } \\
\text { overwintering strategies }\end{array}$ & Quetin and Ross (1991) \\
\hline Winter sea ice extent & $\begin{array}{l}\text { Showed that recruitment success and, hence population size } \\
\text { of krill are linked to extent and duration of winter sea ice } \\
\text { cover, with low ice years related to poor recruitment }\end{array}$ & Siegel and Loeb (1995) \\
\hline $\begin{array}{l}\text { Antarctic photoperiod mediate metabolic } \\
\text { winter depression in krill }\end{array}$ & $\begin{array}{l}\text { Demonstrated from field and laboratory studies the effect } \\
\text { of photoperiod on physiological function of krill }\end{array}$ & $\begin{array}{l}\text { Meyer et al. (2010), } \\
\text { Teschke et al. (2007) }\end{array}$ \\
\hline
\end{tabular}

(Quetin and Ross 1991). The seasonal change in light intensity in the Southern Ocean might also be responsible for seasonal variability in metabolic activity (Kawaguchi et al. 1986; Torres et al. 1994b). Huntley et al. (1994) even showed high metabolic rates and feeding activity on zooplankton of krill during winter and suggested that krill did not adopt specific mechanisms for overwintering.

Until end of the 1990s, although most studies on krill larvae during winter had mainly focused on their distribution and abundance (e.g. Hempel 1985; Daly and Macaulay 1991; Siegel 2005), several studies in the early 1990s investigated the physiological condition of larval krill in winter. At this time, it was not known whether larval krill adapted similar overwintering mechanism to the adults. SCUBA observations indicated that dependence on ice declines during ontogeny with larvae coupled to the underside of sea ice and adults mainly away from it (Quetin et al. 1996; Frazer et al. 1997). Shrinkage of larvae during winter (Ross and Quetin 1991) and low growth have been reported (Daly 1990). In contrast to adults, it has been shown that larvae have low lipid reserves (Ross and Quetin 1991; Hagen et al. 2001). This suggests an inability to survive long starvation periods, making larvae dependent on the biota living within and below sea ice for survival and development (Daly 1990). Stable isotope data and the O:N ratio of winter larvae from the WAP region suggest that algae are the main food source during winter (Frazer 1996; Frazer et al. 2002a), whereas stomach content analyses from the Scotia-Weddell Sea have demonstrated that larvae use heterotrophic organisms and detritus during winter, (Hopkins and Torres 1989; Daly 1990). Few studies on larval overwintering have examined a full suite of ecological measurements and most have been from the WAP region, making wider generalizations difficult (Tables 3 and 4).
In 1999, the Southern Ocean-GLOBal Ocean ECosystem dynamic program was initiated (SO-GLOBEC, 19992009). This program investigated the physical and biological factors that promote krill growth, reproduction, recruitment and survival throughout the year. Field studies took place, in the WAP region, Bellingshausen Sea, Scotia Sea, Lazarev Sea and East Antarctica. Overwintering strategies were identified as an important but largely unknown aspect of krill biology and were addressed through GLOBEC field studies in the WAP and the Lazarev Sea. In the WAP region, the process-oriented winter studies in the program focused mainly on larval krill, and only a few of the proposed overwintering mechanisms were studied (Tables 3 and 4). The Lazarev Sea Krill study (LAKRIS) was the German contribution to SO-GLOBEC. Its major aims were to understand the influence of strongly seasonal environmental factors on the seasonal variation in larval and adult krill physiology and the relative importance of different physiological functions of adults and larvae in overwintering. This project used a consistent multi-analytical approach, to ensure comparability of data throughout seasons to overcome the uncertainties of earlier studies, which investigated only individual aspects of overwintering.

The over-arching aim of the present review is to synthesise findings from the LAKRIS-project with those obtained from previous investigations (Tables 3, 4) to overcome existing uncertainties about overwintering of krill and to deliver a robust and comprehensive view of the annual life cycle of krill from an ecophysiological point of view. The current discussions on a long-term decline of krill abundance in the SW Atlantic sector of the Southern Ocean due to environmental changes will be evaluated with regards to the energetic demands of larval and adult krill throughout the seasons. 


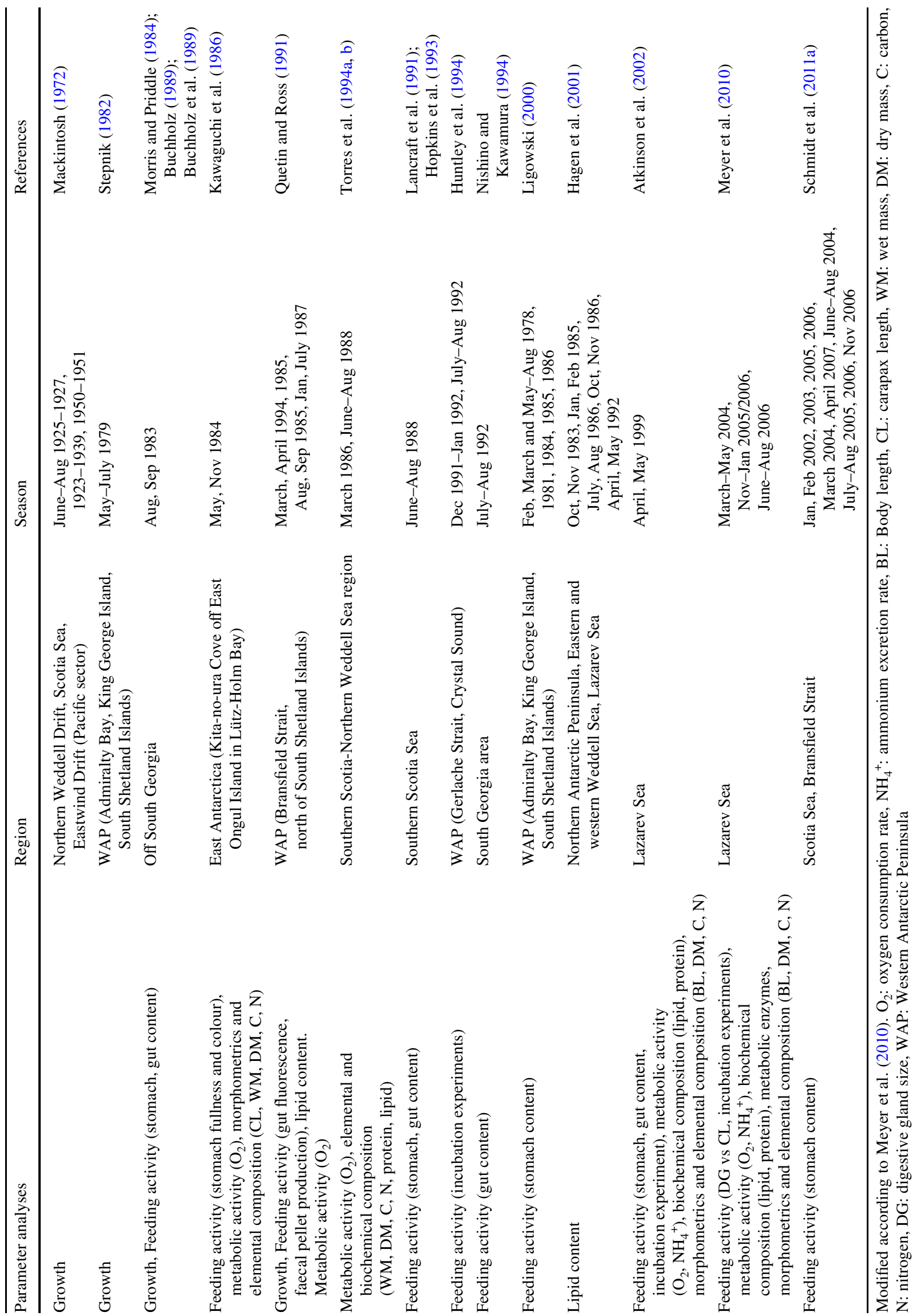




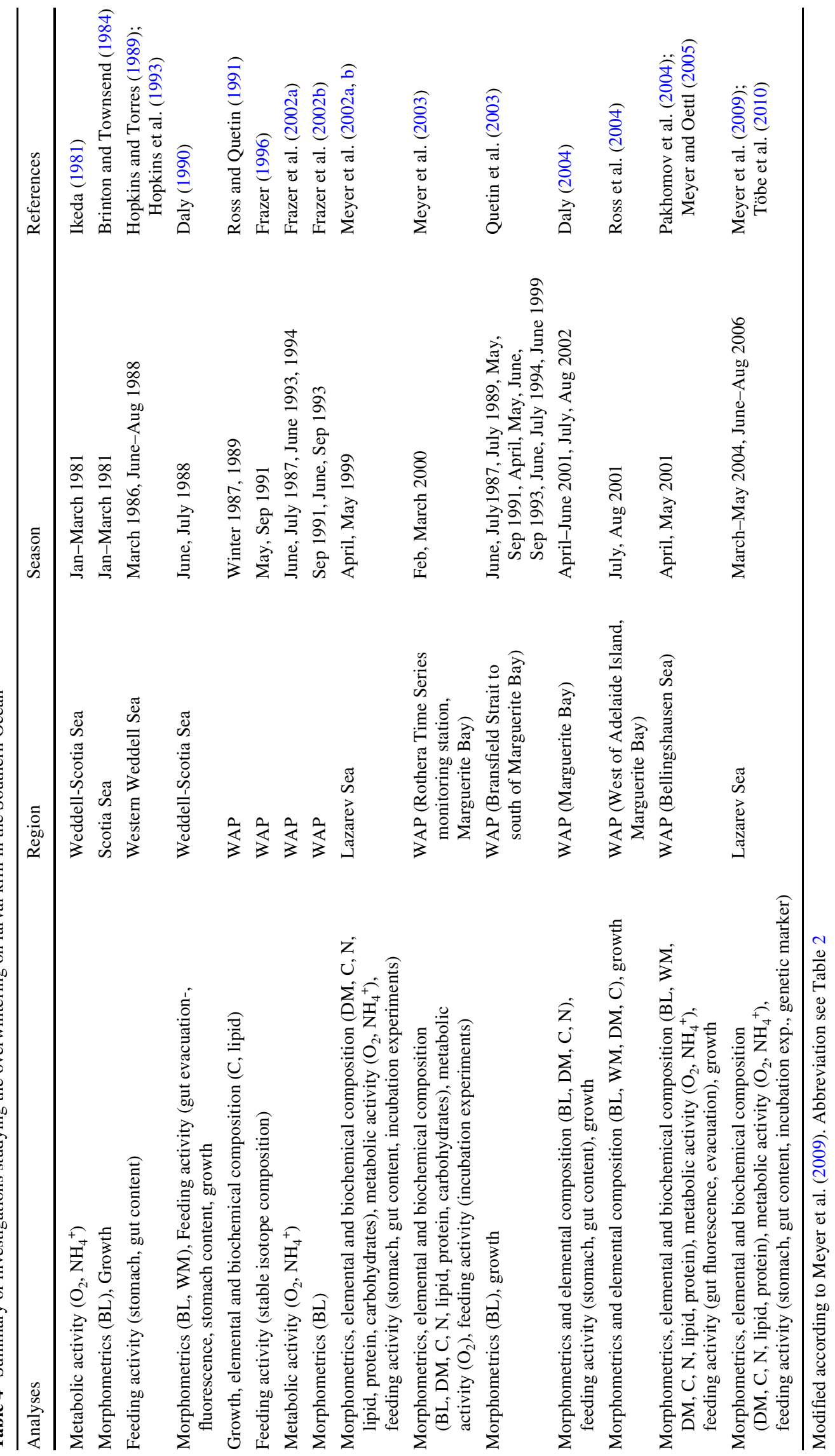




\section{Overwintering mechanisms of adult and larval Antarctic krill}

Adults

\section{Reduction in physiological function in adults}

Oxygen uptake rates of krill around the Antarctic in midlate winter have been shown to be only 30-40\% of summer rates (Kawaguchi et al. 1986; Quetin and Ross 1991; Torres et al. 1994a; Atkinson et al. 2002; Meyer et al. 2010). Additional evidence of metabolic depression in winter krill was the significantly lower activity of the key metabolic enzyme citrate synthase (Meyer et al. 2002a) and malate dehydrogenase (Donnelly et al. 2004). Ambient temperature influences the metabolic rates of ectotherms (Gillooly et al. 2001). However, in the Southern Ocean, water temperature remains within a narrow annual range $\left(-2\right.$ to $\left.2^{\circ} \mathrm{C}\right)$ and hence most likely not the trigger to initiate metabolic winter depression in krill.

Reduced physiological functions of krill in winter are accompanied by low feeding activity and, consequently, growth. Reduced feeding activity of winter krill was shown by low stomach- and/or gut fullness (Morris and Priddle 1984; Kawaguchi et al. 1986; Buchholz 1989; Lancraft et al. 1991; Daly and Macaulay 1991; Nishino and Kawamura 1994; Ligowski 2000) and reduced digestive gland size compared with summer (Meyer et al. 2010; O'Brien et al. 2010). Moreover, reduced rates of faecal pellet production and ingestion of phytoplankton (less than 3\% of summer rates) were observed (Quetin and Ross 1991).

Individual growth rates measured using the Instantaneous Growth Rate (IGR) method (Quetin and Ross 1991; Nicol et al. 1992), showed zero to very low growth during winter in the Lazarev Sea (Meyer et al. 2010), and there was evidence of shrinkage in krill from the WAP region (Quetin and Ross 1991). Studies using length frequency analysis have reported zero to low growth during winter (Mackintosh 1972; Stepnik 1982; Morris and Priddle 1984; Kawaguchi et al. 1986; McClatchie 1988; Buchholz et al. 1989; O'Brien et al. 2010) but also shrinkage (Ettershank 1983; O’Brien et al. 2010).

In winter, low light levels and extensive sea ice coverage limit primary production of phytoplankton drastically and hence limit the main food source of krill. This has been thought to reduce feeding rates and induce starvation which, in turn, causes the slow-down of physiological functions such as metabolism and growth (possibly resulting in shrinkage).

The Antarctic light regime as a potential driving force for the metabolic depression of adult krill in winter Both laboratory and field findings indicate that reduced feeding and metabolic activity during Antarctic winter are not directly caused by food scarcity, but represent an inherent adaptational overwintering mechanism influenced by the Antarctic light regime. So far, it remains unclear as to which lightrelated stimuli (e.g. photoperiod, light intensity or light spectrum) are responsible for the observed effects on physiological functions in krill. It seems most likely that metabolic and feeding activity in winter krill differ with latitudinal region as a consequence of the difference in the photoperiod. The areas south of $60^{\circ} \mathrm{S}$, where krill is most abundant, experience a seasonal light regime with near permanent day in summer and near continuous darkness in winter (Fig. 1). This cue can provide reliable information for the control of physiological processes in krill.

Kawaguchi et al. (1986) demonstrated a decline of feeding and metabolic activity from April/May to the end of September and a slow but steady increase thereafter, at a time when food is still scarce in the water column. This concept, however, was not explored. A compilation of data from investigations on the seasonal metabolic activity of krill in different regions of the Southern Ocean (Fig. 2a) demonstrates their dependency on the corresponding photoperiod (Fig. 2b). In addition, freshly caught krill feed on natural food assemblages in autumn and winter are unable to respond to high food concentrations despite exposure to abundant food for almost 2 weeks (Atkinson et al. 2002; Meyer et al. 2010). The maximum feeding activity of krill was only $20 \%$ (autumn) and $14 \%$ (winter) of summer rates (Meyer et al. 2010). In addition, laboratory experiments have shown that feeding, metabolic activity (Teschke et al. 2007), growth (Brown et al. 2010) and gene expression (Seear et al. 2009) of adult krill are affected by light conditions in terms of different photoperiod. In contrast, recent feeding data from low latitudes (e.g. South Georgia) with a photoperiod in mid-winter between 8 and $9 \mathrm{~h}$ light showed no clear decrease in feeding activity in winter (Schmidt et al. 2011a).

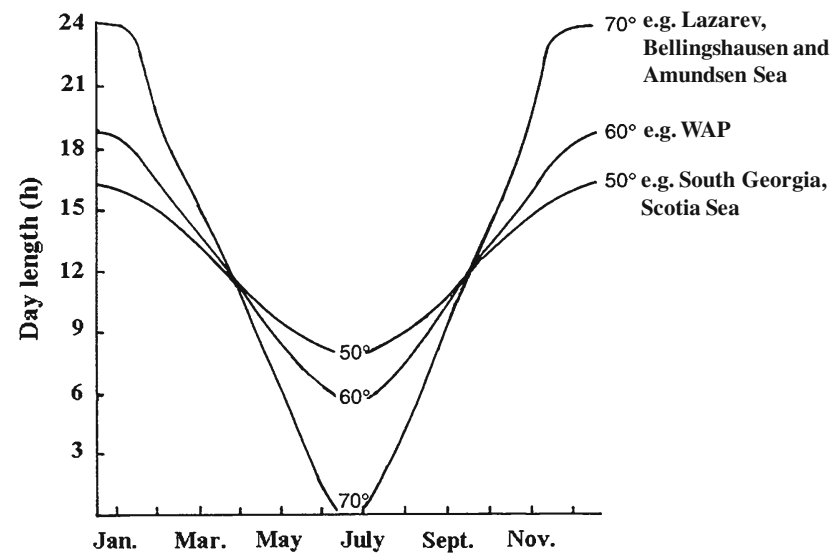

Fig. 1 Latitudinal variation in day length during the year between $50^{\circ}$ and $70^{\circ} \mathrm{S}$. Modified according to Knox 1994 

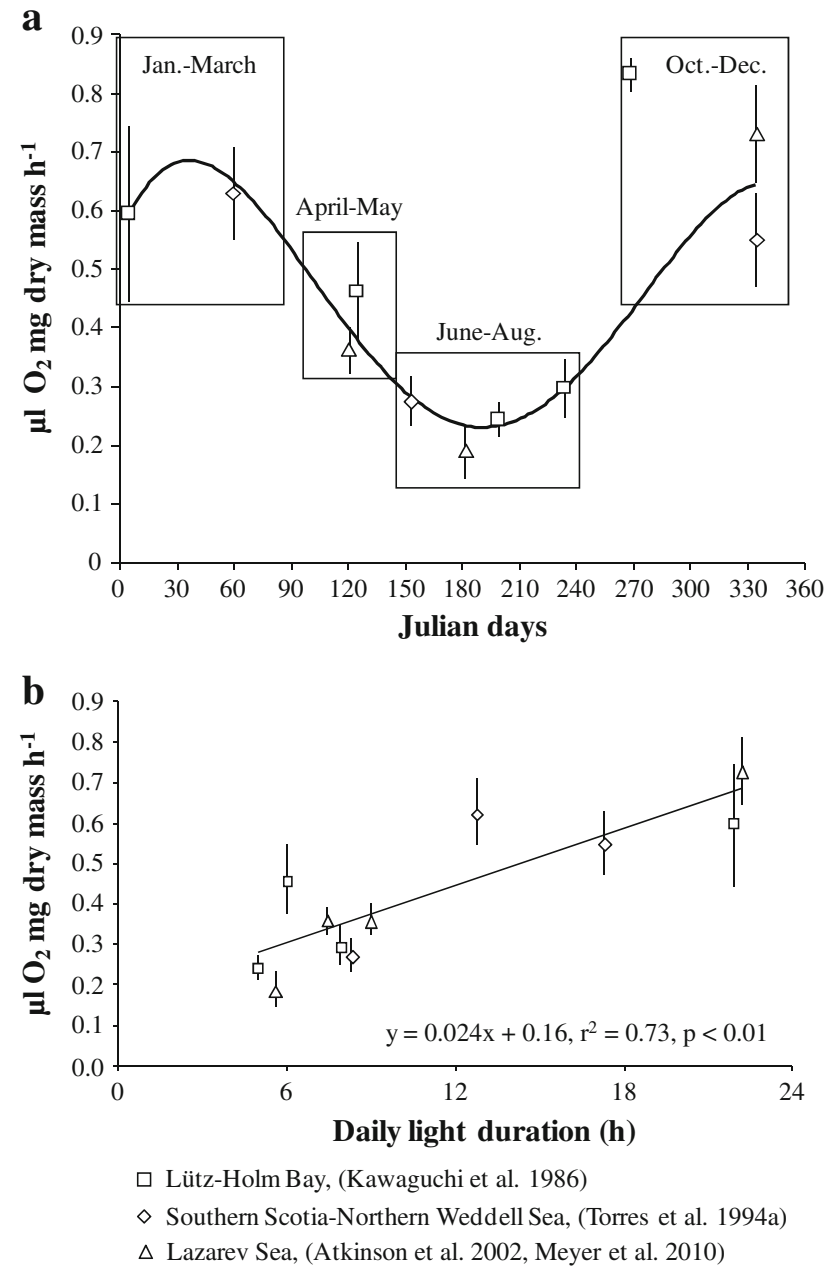

Fig. 2 Seasonal respiration rates of adult krill from different study sites (a) and the correlation between the seasonal respiration rates of adult krill and the corresponding light duration

Teschke et al. (2008) and Brown et al. (2010) demonstrated that the development of external sexual change of krill is accelerated by photoperiod, although others have shown that the cyclic maturation process is maintained independent of direct control by environmental factors such as food or light (Thomas and Ikeda 1987; Kawaguchi et al. 2007). It appears that an endogenous circannual timing mechanism is operating in krill and that photoperiod acts as the main Zeitgeber (synchronising environmental factor). In general, the mechanism of temporal synchronisation of krill to their environment is far from clear. It remains unclear how changes in the light regime are received by krill and how they trigger specific physiological reactions. Recent studies provide evidence that the synchronisation of krill to its environment depends upon an endogenous circadian clock (Teschke et al. 2011). Such a clock would be entrained by external environmental signals and controls circardian phenotypes and also may modulate photoperiodic responses (Gaten et al. 2008; Mazzotta et al. 2010).
Future studies are required to pursue the characterisation of a circardian/circannual clock in krill and to unravel the role of an endogenous timing system in the rhythmic and synchronised daily and seasonal behaviours of krill. The hormone melatonin does not seem to play a role in the control of seasonal metabolic changes in krill (Pape et al. 2008), even though it is involved in vertebrate and numerous nonvertebrate taxa in the transduction of photoperiodic information (e.g. Tilden et al. 2001).

The influence of the changing day length in the Southern Ocean on the metabolic activity of krill appears to vary with krill age (Fig. 3). Based on the correlation between the size of krill and their corresponding individual oxygen uptake rates, the larger the animals, the more distinctive the differences in metabolic rates between seasons. It is unknown at which developmental stage (e.g. 1 year old krill) the shift of metabolic activity between seasons takes place.

\section{Energy provision of adult krill}

Although physiological functions are reduced to a minimum, energy must still be provided in order for the organism to function, albeit at low rates, for several months during the absence of autotrophic food in the water column. There seem to be two adaptations to accomplish this: (1) accumulation of large lipid reserves during summer for winter utilisation, (2) an omnivorous feeding at low rates during winter and (3) shrinkage.

Body lipid and protein utilisation The body lipid contents of krill from different regions show a strong seasonality, with highest levels in late autumn and minimum values in mid-spring (Table 5) that correspond to a utilisation of body lipids in krill at a rate of $10 \% \mathrm{DM}^{-1}$ month $^{-1}$ from April/May to October/November. The importance of lipid utilisation of winter krill is further highlighted by the high $\mathrm{O}: \mathrm{N}$ ratios (average 66) and the high activity of the metabolic enzyme 3-hydroxyacyl-CoA dehydrogenase (HOAD), an indicator for lipid breakdown (turnover), compared with values from summer and autumn (Meyer et al. 2010).

Survival of adult krill through winter and reproductive success in the subsequent summer, however, depend on the accumulated energy reserves at the onset of winter. Completely depleted body lipids at the start of the reproductive season would affect the onset and maintenance of reproduction in krill and hence their reproductive success (Clarke and Morris 1983; Cuzin-Roudy and Labat 1992; Quetin et al. 1994). The development of external maturation characteristics during winter, the first step in the reproduction cycle, seems to be fuelled preferentially by lipid reserves (Teschke et al. 2008), highlighting the importance of a sufficient accumulation of lipids at the commencement of 


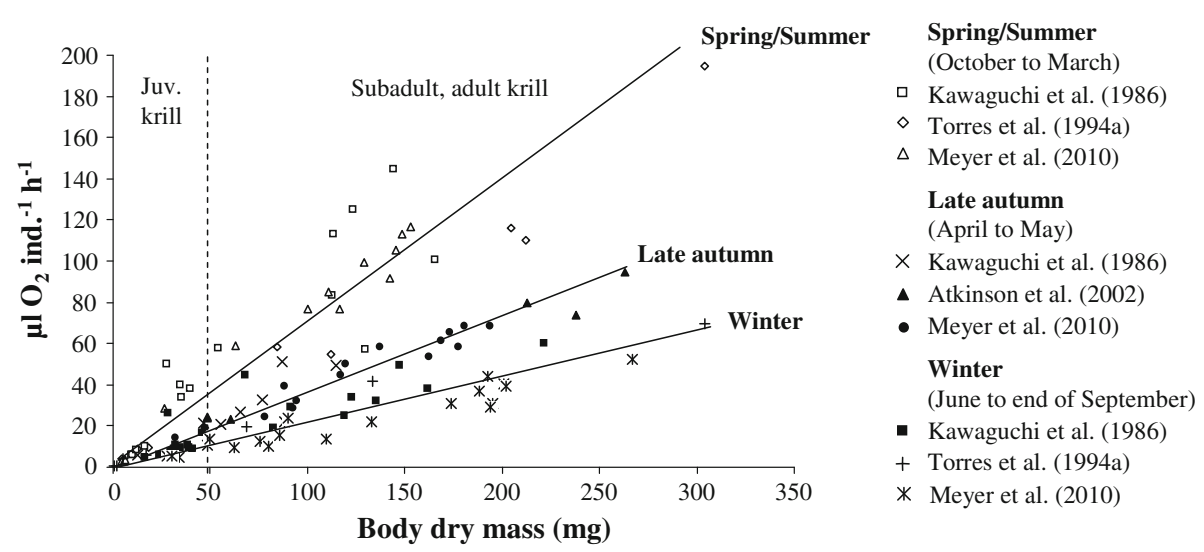

Fig. 3 Relationship between body dry mass and individual oxygen uptake rates in different seasons and latitudinal regions in the Southern Ocean. Juvenile, subadult and adult krill were defined according to Siegel (1987). The equations are as follows: Spring/Summer: $y=0.69 x, r^{2}=0.86, n=36$; late autumn: $y=0.37 x, r^{2}=0.93, n=29$;

Table 5 Seasonal body lipid content per dry mass (DM) of adult krill from different regions and seasons

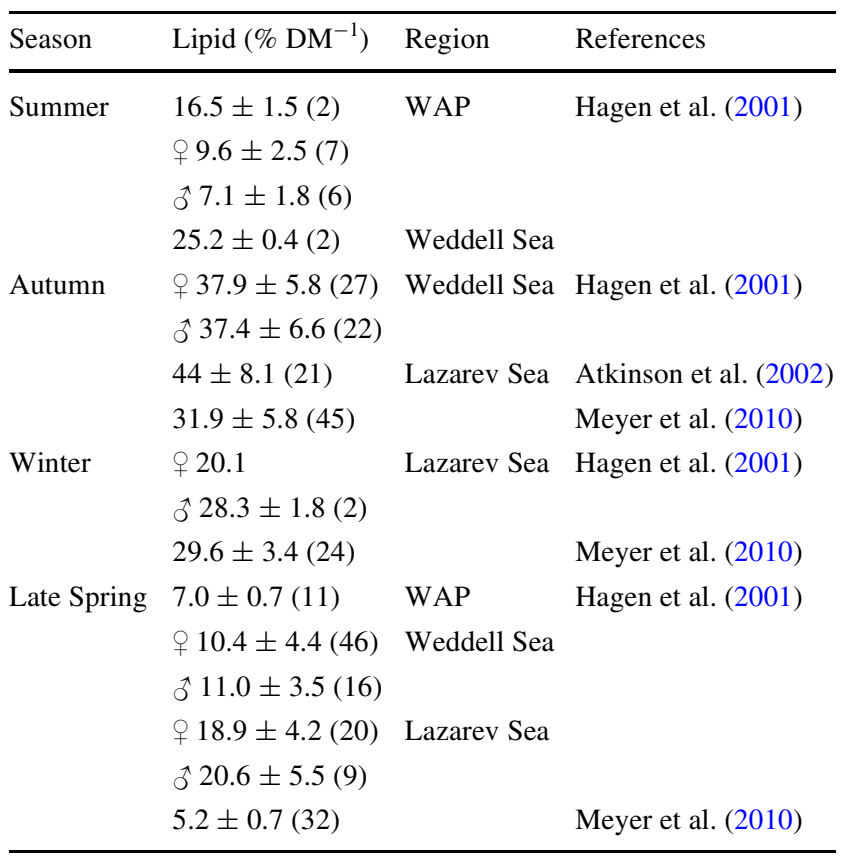

Number of replicates in brackets

winter. The amount of energy reserves at the onset of winter depends on the quantity and quality of phytoplankton during the preceding summer and autumn (Hagen et al. 2001).

Compared with lipids, proteins play a minor role as an energy reserve in krill for overwintering. Investigations in the Lazarev Sea and the Southern Scotia-Northern Weddell Sea region have demonstrated that ca. $3 \%$ body protein $\mathrm{DM}^{-1}$ month $^{-1}$ were utilised by krill during winter (Meyer et al. 2010). However, protein metabolism may play an winter: $y=0.22 x, r^{2}=0.78, n=49$. The regions were the oxygen uptake rates were measured are as follows: Lütz-Holm Bay (Kawaguchi et al. 1986), Southern Scotia-Northern Weddell Sea (Torres et al. 1994a), Lazarev Sea (Atkinson et al. 2002, Meyer et al. 2010)

important role in summer. In different regions of the Southern Ocean, krill showed a low O:N ratio of $<15$ during the feeding season from spring to autumn (Ikeda and Mitchell 1982; Atkinson et al. 2002; Meyer et al. 2010), suggesting that lipids are being accumulated for utilisation during winter rather than used for energy turnover, which might be covered by protein metabolism.

The use of food sources other than phytoplankton from the water column Overwintering krill appear to feed opportunistically and can switch to alternative food sources such as ice algae, zooplankton and/or phytodetritus (Table 6).

The colouration of the digestive gland and the stomach is related to the food source (Kawaguchi et al. 1986, 1999; Nicol et al. 2004). Phytoplankton diet is indicated by a black green, yellow and/or greenish digestive gland (Kawaguchi et al. 1999), phytodetritus by a brownish ochre stomach (Kawaguchi et al. 1986), and a milky-white digestive gland is an indicator for a zooplankton diet (Atkinson et al. 2002). In the Lazarev Sea, the digestive gland in winter was half the size of that in late spring and its colouration ranged from colourless to milky white or pale yellow (Fig. 4), suggesting that krill had either not been feeding or had ingested heterotrophic and autotrophic food at low rates.

In contrast to other overwintering studies, Huntley et al. (1994) reported high feeding activity of krill on small zooplankton organisms such as Oithona and Oncea and Marschall (1988) on sea ice algae in winter. Actually, the latter study took place at the onset of spring and not as the title states in winter (Hempel 1987). Feeding activity, growth and metabolic rate are increasing in spring despite low food supply (Mackintosh 1972; Stepnik 1982; Morris and Priddle 1984; Kawaguchi et al. 1986). Therefore, it is most 
Table 6 Feeding activity of adult krill in the field during Antarctic winter

\begin{tabular}{lll}
\hline Measurements & Field results & References \\
\hline Stomach and gut content & Phytoplankton: (Diatoms, dinoflagellates, silicoflagellates) & $\begin{array}{c}\text { Lancraft et al. (1991); Hopkins et al. (1993); } \\
\text { Nishino and Kawamura (1994); }\end{array}$ \\
& Protozoans: (Tintinnids, foraminifera, naked ciliates) & Kawaguchi et al. (1986); Ligowski (2000) \\
& Metazoans: (Oithona and other copepods) & \\
& Euphausiid debris: (Moults) & Buchholz (1989) \\
& Empty or contained undefined detritus & Daly and Macaulay (1991) \\
Colour of stomach & Light green & Kawaguchi et al. (1986) \\
and gut content & Yellowish brown or ochre & Buchholz (1989) \\
Colour of digestive gland & Whitish to translucent & Guzmán (1983) \\
& Clear or opaque & Meyer et al. (2010) \\
\hline
\end{tabular}

Modified according to Meyer et al. (2010)
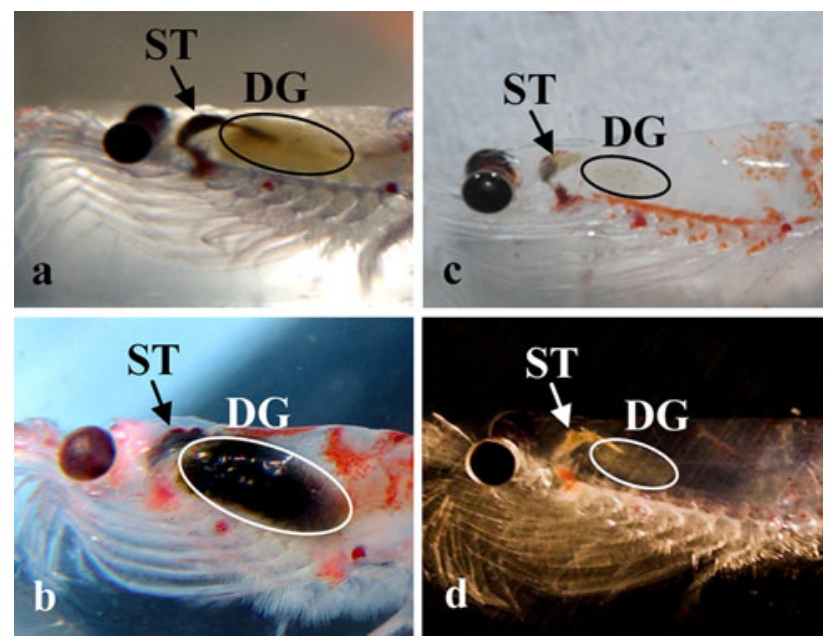

Fig. 4 Carapace with digestive gland (DG) and stomach (ST) of freshly caught adult krill; a yellow and $\mathbf{b}$ green-black DG in late spring, and c milky white and d pale yellow DG in winter (from Meyer et al. 2010)

likely, at the time when the observations of Marshall (1988) occurred once physiological winter depression had already been terminated by a Zeitgeber cue (e.g. photoperiod) and animals had returned to an active physiological state.

Benthic feeding by krill has been observed on a number of occasions, and it was assumed that the usual depth habitat of adult krill during summer is between 100 and $200 \mathrm{~m}$ (e.g. Siegel 1986). However, some summer studies have recorded near-bottom or on-bottom foraging of krill at depths of 400-450 $\mathrm{m}$ in the Weddell Sea (Gutt and Siegel 1994), $500 \mathrm{~m}$ in the Bransfield Strait, $400-700 \mathrm{~m}$ off East Antarctica (Kawaguchi et al. 2011) and $1,000 \mathrm{~m}$ in the Drake Passage (Marin et al. 1991). Krill have also been observed feeding at abyssal depth $(3,000-3,500 \mathrm{~m})$ in Marguerite Bay (Clarke and Tyler 2008). In winter, krill detected by the fishery were deeper than 100-200 m depth (Taki et al. 2005), and stomach analyses indicated that krill were feeding near or on the bottom (Kawaguchi et al. 1986;
Ligowski 2000). A recent study found adult krill near the seafloor in many regions and during all seasons in the Southern Ocean, indicating the ability to utilise benthic detritus to supplement diet throughout the year (Schmidt et al. 2011a).

Shrinkage of adult krill during winter A long-term laboratory study published in 1982 by Ikeda and Dixon demonstrated that krill are able to shrink when food is absent, but it is still unclear to what extent this occurs under natural conditions. Table 7 gives an overview when and where shrinkage was observed in the Southern Ocean. Former winter growth studies using the traditional length frequency analysis at the population level have reported zero or low growth (Mackintosh 1972; Stepnik 1982; Morris and Priddle 1984; Kawaguchi et al. 1986; Siegel 1987; McClatchie 1988; Buchholz et al. 1989). Also recent growth studies using the instantaneous growth rate (IGR) method showed a mean positive growth even when shrinkage was observed (Atkinson et al. 2006; Meyer et al. 2010). In both investigations, shrinkage was associated with unfavourable environmental conditions in terms of low Chl $a$ concentration (Atkinson et al. 2006) and severe physiological conditions in terms of body lipid level (Meyer et al. 2010). On the other hand, shrinkage was also observed in females at the end of the reproductive season in April (Kawaguchi et al. 2006). For better understanding as to when and why shrinkage of krill occurs in the field, analyses of seasonal growth, distinguished by sex, in addition to environmental conditions (e.g. food supply in terms of Chl $a$ ), and condition indicators of krill (e.g. body carbon, lipid content, lengthmass relationships) are required from future research.

\section{The role of sea ice for overwintering success of adult krill}

Mackintosh (1972) first linked the overall distribution of krill to the distribution of sea ice, and Hamner et al. (1983) 
Table 7 Regions and seasons when skrinkage was observed in krill by using the instantaneous growth rate (IGR) method and lengthfrequency method (LFM)

\begin{tabular}{llll}
\hline Region & Season & Method & References \\
\hline WAP & Winter & IGR & Quetin and Ross (1991) \\
Lazarev Sea & & IGR & Meyer et al. (2010) \\
East Antarctica & & LFM & Ettershank (1983) \\
& Winter/spring & IGR & O'Brien et al. (2010) \\
& Summer & IGR & Nicol et al. (1992) \\
$\begin{array}{c}\text { Scotia Sea, } \\
\text { South Georgia }\end{array}$ & & IGR & Atkinson et al. (2006) \\
East Antarctica & Autumn & IGR & Kawaguchi et al. (2006) \\
\hline
\end{tabular}

reported krill feeding on ice algae, suggesting an underlying reason for the linkage. The discovery that juvenile and adult krill are adapted to feeding on ice algae was at first believed to be the answer to the long-standing question of how krill survive the winter season of low food supply in the water column (e.g. Smetacek et al. 1990). In mid-winter, however, the ice algae community is not well developed (Fig. 5a) as the sea ice is growing continuously and light is limited. High numbers of small zooplankton organisms, however, such as Oithona spp and Oncea spp. and copepodide stages of Calanus propinguus, Metridia gerlachei and other calanoid species have been observed beneath sea ice in winter, which might provide a ready food source for adult krill (Tanimura et al. 1986; Schnack-Schiel et al. 1998; Meyer et al. 2010). In contrast, when spring commences, the sea ice begins to erode and the well-developed sea ice algae (Fig. 5 b) become then readily accessible to krill (Thomas and Dieckmann 2003). Due to the specific physiological overwintering mechanisms of adult krill (reduced metabolism and feeding activity), the sea ice as a feeding ground may be relatively unimportant for krill during mid-winter. However, the importance of sea ice for the adults increases in early spring, when they revert to an active mode after termination of metabolic depression. This concept is supported by the available observations (Spiridonov et al. 1985; O’Brien 1987; Marschall 1988; Bergström et al. 1990; Spiridonov 1992; Quetin et al. 1994, 1996; Frazer et al. 1997; Lawson et al. 2008; Quetin and Ross 2009; Meyer et al. 2010).

Surveys by remote operating vehicles (ROV) or SCUBA divers in different regions of the Southern Ocean during winter (Bransfield Strait, Lazarev Sea, the WAP region) have only seldom observed adult krill associated with sea ice (Quetin et al. 1994, 1996; Frazer et al. 1997; Lawson et al. 2008; Quetin and Ross 2009; Meyer et al. 2010). Net surveys in the Gerlache Strait during winter found maximal krill abundance between 15 and $50 \mathrm{~m}$ depth (Nordhausen 1994; Zhou et al. 1994). Fisheries research from different regions in the Scotia Sea demonstrated that, in winter, the highest densities of krill were found between 80 and $240 \mathrm{~m}$ depth, whereas they aggregated at the surface and up to $60 \mathrm{~m}$ depth in spring and summer (Taki et al. 2005). In the Lazarev Sea, a surface under-ice trawl (SUIT) caught adult krill in the upper $2 \mathrm{~m}$ under sea ice at night in winter with an average abundance of 2.7 ind. $\mathrm{m}^{-2}$ from 30 hauls (Flores et al. 2011). Despite the paucity of winter observations, these findings suggest that adult krill is not regularly associated with sea ice during winter.

With the increasing daily light duration in early spring (from the end of September onwards), metabolic activity of adult krill increases (Fig. 2a) to fuel general development, growth, gonad development and reproduction (Ross and Quetin 1986; Quetin and Ross 2001). At this time of the year, the ice algae community is well developed and becomes important for the adults in order to meet their high energetic demands. In spring, feeding on a well-developed under-ice algae community when present is, therefore, presumably a regular behaviour of adult krill. Observations by SCUBA divers and ROVs, from early spring onwards, have provided direct evidence for the presence of adult krill in very high abundance (several $100-1,000$ ind. $\mathrm{m}^{-2}$ ) under sea ice when a well-developed ice algae community is present (Spiridonov et al. 1985; O'Brien 1987; Marschall 1988; Bergström et al. 1990; Spiridonov 1992). Their dark green digestive glands indicated active feeding on the sea ice algae biota (Marschall 1988). Moreover, acoustic surveys determined large aggregation of krill under the ice during
Fig. 5 Typical underside of sea ice in the Lazarev Sea with regard to the development of the ice algae community in mid-winter (a) and early spring (b)
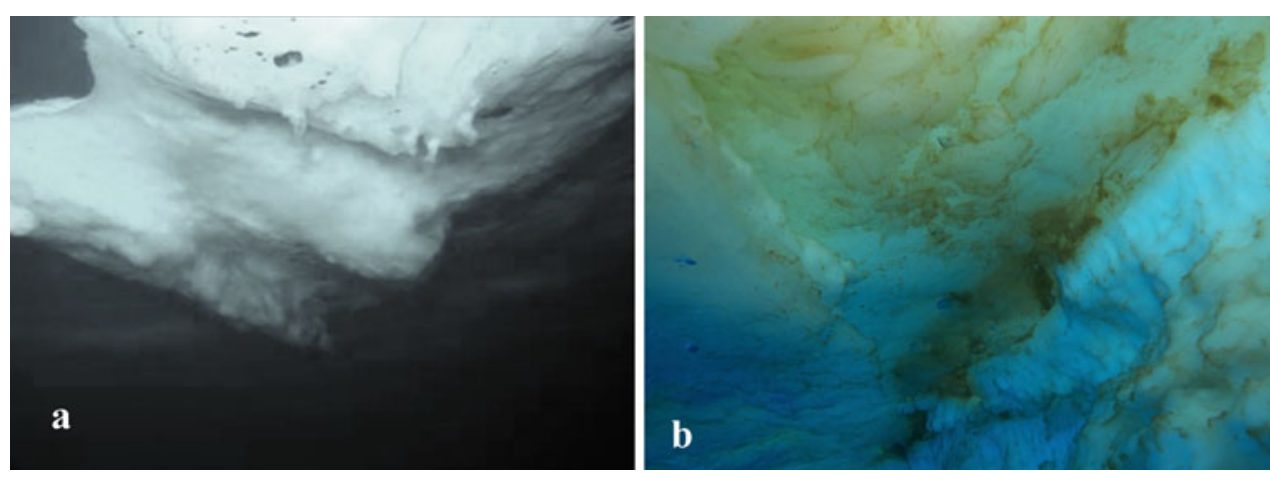
summer (e.g. Brierley and Watkins 2000; Brierley et al. 2002).

The role of sea ice for adult krill during the course of the year can be summarised as follows. During summer, krill reside in high densities in the upper $200 \mathrm{~m}$ of the water column, often concentrated in organised swarms (schools) in close proximity to their food. Feeding takes place wherever high amounts of food are available (open water, ice edge zone, under sea ice, etc.). At the onset of winter, when their metabolism is depressed, it was hypothesised from net and acoustic surveys that krill migrate inshore (Siegel 1989; Lascara et al. 1999; Zhou et al. 1994; Nordhausen 1994; Lawson et al. 2008) to over-winter at depths over $200 \mathrm{~m}$. Numerous aggregations were observed during winter in Marguerite Bay at depths greater than $150 \mathrm{~m}$. This pattern, however, seems inconsistent throughout the years observed (Lawson et al. 2008), demonstrating the highly variable nature of krill distribution during winter. In winter, adults feed opportunistically at low rates. This energy input, even at low rates, complements reduced metabolism and lipid utilisation and is a requirement for successfully reproducing in subsequent spring. At the beginning of spring, when adult krill revert to their active mode, they have to feed on large phytoplankton concentrations (mainly diatoms) wherever they occur (under sea ice, ice edge zone, open water) to meet their high metabolic demands such as for ovary maturation.

\section{Energy budget of adult krill during winter}

A comprehensive review of krill energetic was first published by Clarke and Morris (1983) and later updated by Quetin et al. (1994). In these reviews, adult krill energetic during winter was a topic of large uncertainties due to the lack of data. Since then, the knowledge on metabolic depression and lipid utilisation of winter krill has progressed. This large body of information will be used below to calculate an energy budget for the period from the beginning of April (the start of the metabolic depression) to the end of September (spring, 189 days) when adults revert to an active mode. This is aimed at complementing the existing reviews of krill energetic.

Equations from regressions in Fig. 3 were used to calculate daily energy requirements from the beginning of April to end of September, (April and May, 61 days: $\mu 1 \mathrm{O}_{2}$ ind. $\mathrm{h}^{-1}=0.37 \times \mathrm{DM}$ in $\mathrm{mg}$; June until end of September, 122 days: $\mu \mathrm{l} \mathrm{O}_{2}$ ind. $\mathrm{h}^{-1}=0.22 \times \mathrm{DM}$ in $\mathrm{mg}$ ). The calculated respiration rates as a measure of total metabolism, which represents the sum of krill's energetic needs, were converted to energy consumption rates, assuming an equivalent of $19.40 \mathrm{~J} \mathrm{ml} \mathrm{O} \mathrm{O}_{2}$ (Brett and Groves 1979). Hence, a $200 \mathrm{mg}$ krill would consume about $1.8 \mathrm{ml} \mathrm{O}_{2}$ daily in April and May and $1.1 \mathrm{ml}$ from June to the end of September.
This translates into a total demand of $4,734 \mathrm{~J}$ to cover metabolic activity for the 6 month of physiological winter depression.

As outlined above, krill use high amounts of body lipid and moderate amounts of body protein reserves at rates of 10 and 3\%, month ${ }^{-1}$, respectively. During the 6 months of metabolic winter depression, krill consume $37 \mathrm{mg}$ of body lipids and $13 \mathrm{mg}$ of body proteins, which corresponds to an energy yield of 1,484 $\mathrm{J}$ from lipids and $255 \mathrm{~J}$ from proteins, assuming conversion factors of $39.6 \mathrm{~J} \mathrm{mg}^{-1}$ for lipid and $20.1 \mathrm{~J} \mathrm{mg}^{-1}$ for protein (Brett and Groves 1979). The difference of 2,995 J between the energy consumed and that provided from body reserves of lipids and proteins for the period from April to the end of September corresponds to an estimated $16 \mathrm{~J} \mathrm{day}^{-1}$ krill have to obtain from food. This daily energy requirement, equivalent to $0.3 \mathrm{mg} \mathrm{C}$ with an energy yield of $45.7 \mathrm{~J} \mathrm{mg} \mathrm{C}{ }^{-1}$ (Salonen et al. 1976), equates to, e.g., one Calanus propinquus copodite (C) $\mathrm{V}$ and two C. acutus CV. Microscopic analysis of the stomach and gut contents of winter krill (Table 6) and feeding rates of adult krill in their winter depression (Atkinson et al. 2002) demonstrate that krill could gain $0.3 \mathrm{mg} \mathrm{C}$ day $^{-1}$ by occasional feeding, even at low rates. This energy budget demonstrates that the feeding activity during winter, although very low, is an essential part for a successful overwintering of krill and that without feeding, krill would enter spring with an energy deficit. A $200 \mathrm{mg}$ krill with an initial amount of $80 \mathrm{mg}$ lipid $\mathrm{DM}^{-1}$ and $76 \mathrm{mg}$ protein $\mathrm{DM}^{-1}$ when entering its winter depression mode would still contain $42 \mathrm{mg}$ lipids (ca. $20 \% \mathrm{DM}^{-1}$ ) and $63 \mathrm{mg}$ proteins (ca. $30 \% \mathrm{DM}^{-1}$ ) at the end of the physiological winter depression (Fig. 6). This is a reasonable amount to start the spring season in favourable physiological condition. Experimental (Teschke et al. 2008) and field data (Siegel 1988) suggest that the external maturation (thelycum development) seem to be mainly fuelled by the utilisation of lipid reserves during winter, whereas the subsequent ovary development is fuelled by high feeding activity on large phytoplankton assemblages (mainly diatoms) after the metabolic winter depression (Ross and Quetin 2000, Schmidt et al. 2011b). This calculation emphasises the importance of the initial lipid level of krill when entering the winter metabolic depression phase. It also highlights the significance of finding high food concentration when the energetic demands are high after physiological winter depression ends and the reproductive season commences.

\section{Larval krill}

The reproductive period of krill is restricted to a 1.53 month season during the Antarctic summer, alternating with a long period of gonadal rest (Ross and Quetin 2000). After spawning, eggs sink to depths of $800-1,000 \mathrm{~m}$ and 


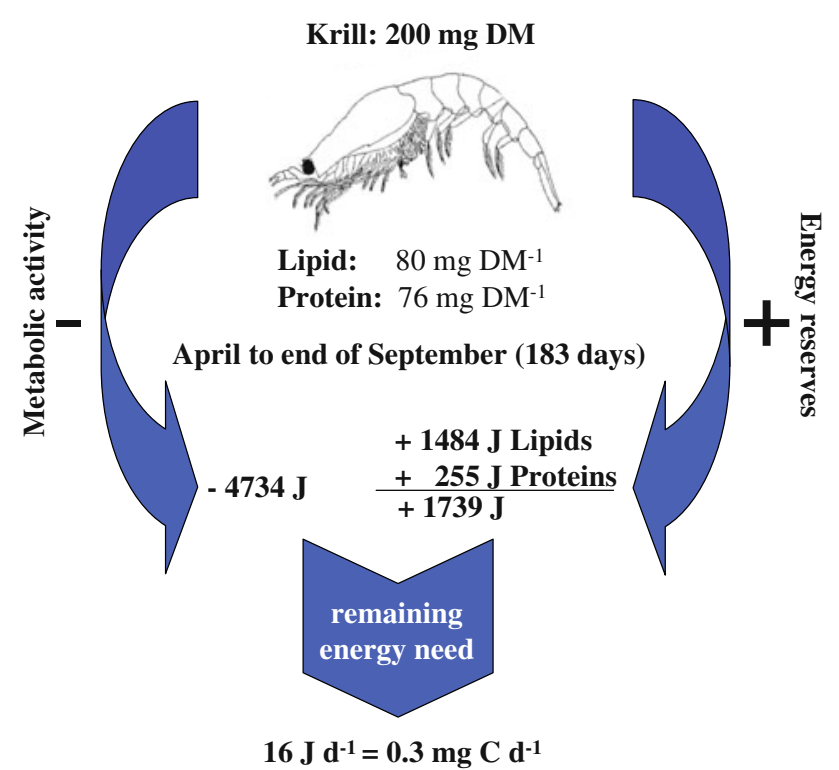

Fig. 6 Energy budget of adult krill of $200 \mathrm{mg}$ dry mass (DM) from the onset of winter to beginning of spring (begin of April until end of September)

hatch. The nauplius larvae commence their re-ascent to the surface while developing via the metanauplius stage to the calyptopis larvae. The calyptopis I stage is the first feeding stage of krill (Ross and Quetin 1989). Krill ontogenesis proceeds via two more calyptopis stages, followed by six furcilia stages, which develop during summer, autumn and winter and recruit to the juvenile population in the following spring.

\section{Physiological condition of larvae in different seasons and regions}

Body length, elemental composition and growth The high inter-annual variability in phytoplankton concentration in the water column during summer and autumn, and the sea ice dynamics and micro algal biomass in winter and spring pack ice, has an important impact on the condition and hence development of larval krill (Ross and Quetin 1991; Meyer et al. 2002b, 2003, 2009; Quetin et al. 2003). Seasonal variations in body length and dry mass are very similar in larvae from different regions (Fig. 7). Comparable regressions exist between dry mass and carbon and nitrogen of larvae from the WAP region and the Lazarev Sea.

The growth rates of larval krill measured with the instantaneous growth rate (IGR) method are highly variable from the onset of winter in April until its end in September. They range on average from $15 \%$ growth per moult in autumn (Pakhomov et al. 2004) to negative values (body shrinkage) in mid-winter (Quetin et al. 2003; Ross et al. 2004). A comparison of growth rate data from autumn and winter larvae from the WAP region and the Lazarev Sea has demonstrated that larval krill follow a specific growth pattern from late autumn to winter (Fig. 8). The larvae had a clear positive growth in April, a steady decrease in growth rates until
Fig. 7 Relationship between body length and dry mass of larval krill from different regions in the Southern Ocean. The equations demonstrate the best fit of all data and are as follows: Summer: $y=0.0027 x^{2.65}$, $r^{2}=0.68, n=19, P<0.01$, autumn: $y=0.0123 x^{1.93}$, $r^{2}=0.71, n=24, P<0.001$, winter: $y=0.0013 x^{2.84}$, $r^{2}=0.91, n=14, P<0.001$. Modified according to Meyer et al. (2009)

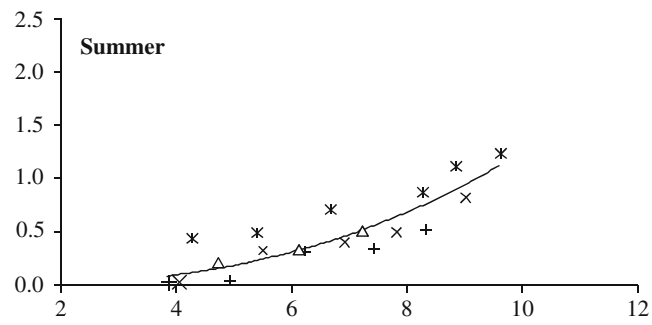

* WAP(Gerlaiche St., Huntley and Brinton 1991)

$\times$ WAP(Bransfield St., Huntley and Brinton 1991)

+ WAP(Drake Passage, Huntley and Brinton 1991)

$\triangle$ WAP(Marguerite Bay, Rothera Point, Meyer et al. 2003)

$\diamond$ WAP(Marguerite Bay, Daly 2004)

○ WAP(Bellingshausen Sea 2001, Pakhomov et al. 2004)

- Lazarev Sea ( Meyer et al. 2009)
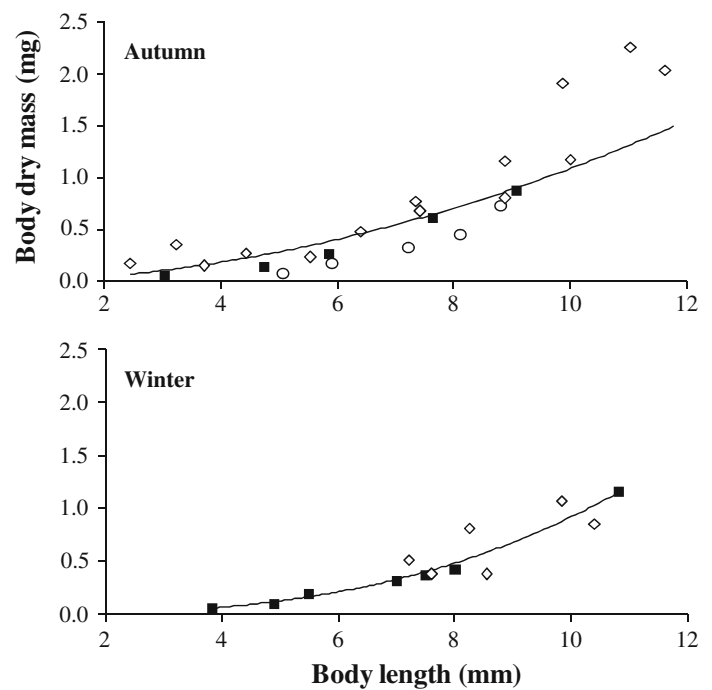


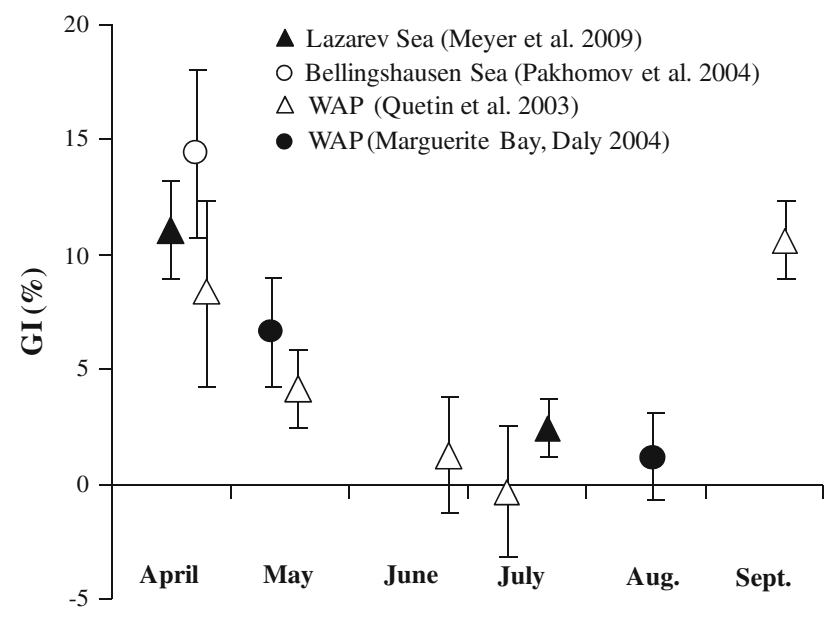

Fig. 8 Average growth rates of larval krill, measured with the instantaneous growth rate (IGR) method (Meyer et al. 2009), from different regions and years given as growth increment (GI) in \% change in uropod or telson length at moulting. WAP means different study regions west of the Antarctic Peninsula. The data from Fig. 5 in Quetin et al. (2003) were extracted with the image processing program ImageJ. The number of growth data were as follows: Pakhomov et al. 2004, April: $n=9$; Meyer et al. 2009, April: $n=6$, July: $n=5$; Daly 2004, May: $n=7$, August: $n=6$; Quetin et al. 2003, April $n=3$, May: $n=8$, June: $n=13$, July: $n=3$, September: $n=16$

a minimum from June to August and a recurring increase of their growth rates in September (Fig. 8). This growth pattern reflects the high variability in food supply during the period from late autumn until the end of winter. The intermoult period (IMP) in winter is mainly double that in summer and autumn (Quetin et al. 2003; Meyer et al. 2009).

Surface layer Chl $a$ is a surprisingly good overall predictor of larval growth in the WAP and the Lazarev Sea, (Fig. 9). This basic relationship, however, only holds because winter $\mathrm{Chl} a$ concentrations and larval growth rates are much lower than those during autumn. Therefore, the use of water column Chl $a$ concentration as a proxy to predict growth is most precise in autumn, but less reliable in winter when growth varies greatly, e.g., from 1 to $4 \%$ in uropod length at moulting (Daly 2004; Meyer et al. 2009), despite very low Chl $a$ concentrations $\left(<0.03 \mu \mathrm{g} \mathrm{Chl} a 1^{-1}\right)$. Thus, some other energy sources than algal diet must be used by the larvae to explain this high variability during winter. In autumn, maximum growth was reached at a $\mathrm{Chl}$ $a$ concentration $>1 \mu \mathrm{g} 1^{-1}$.

In mid-winter in the WAP region and the Lazarev Sea, the majority of FVI larvae moulted to the same stage, whereas FIV and FV larvae moulted to an intermediate form before moulting into subsequently FV and FVI stage, respectively (Daly 2004; Meyer et al. 2009). This might be an adaptation mechanism to avoid the development to the juvenile stage, with much higher energy demands, already in mid-winter (Feinberg et al. 2006).

Metabolic and feeding activity Larvae show no significant differences in metabolic activity, measured as respiration rates, between summer and autumn, ranging from 0.7 to $1.4 \mu \mathrm{l} \mathrm{O}_{2} \mathrm{mg} \mathrm{DW} \mathrm{h}^{-1}$ (Ikeda 1981; Meyer et al. 2002a, b, 2003, 2009), whereas in winter, the respiration rates are only half of those in summer (Frazer et al. 2002a; Meyer et al. 2009). The respiration rates of freshly caught larvae from mid-winter are comparable with rates of furcilia from late summer and autumn starved for 1 week (Fig. 10a, Meyer et al. 2002a). Oxygen consumption increased in larval krill with temperature (Frazer et al. 2002a, b). However, the low temperature differences between summer and winter $\left(+1.5^{\circ} \mathrm{C},-1.8^{\circ} \mathrm{C}\right.$, respectively) do not account for the large differences in oxygen uptake rates between seasons.

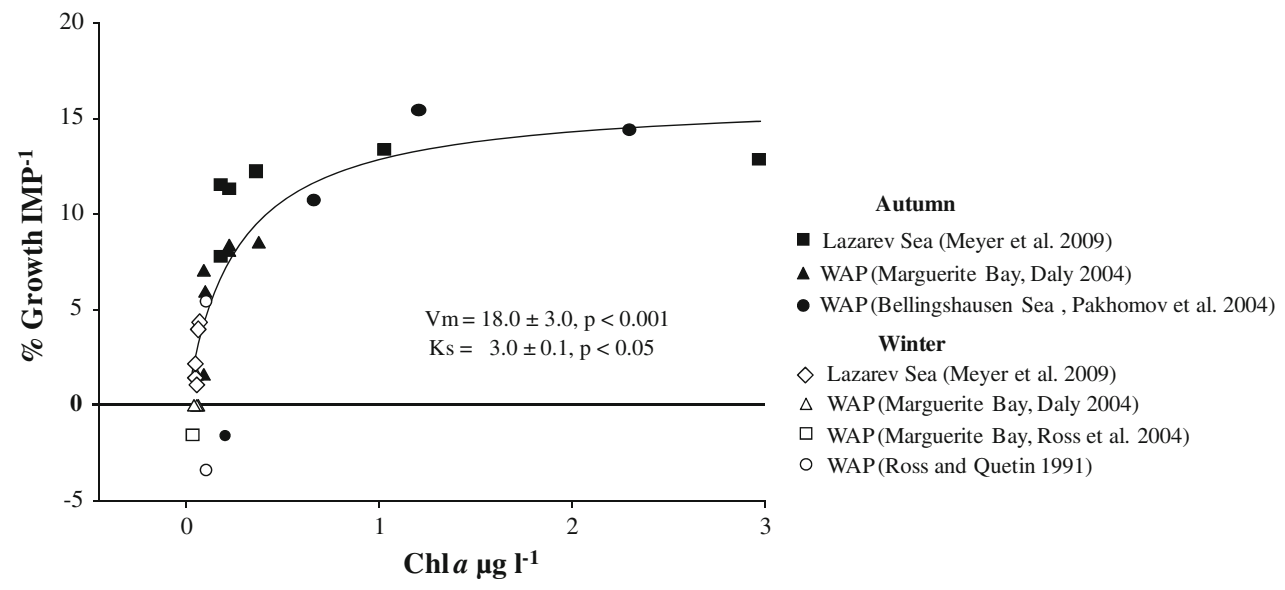

Fig. 9 Relationship between mean chlorophyll $a(\mathrm{Chl} a)$ concentration and $\%$ growth per intermoult period $\left(\mathrm{IMP}^{-1}\right)$ of larval krill from autumn and winter in different regions in the Southern Ocean (modified according to Meyer et al. 2009). Data are expressed as a MichaelisMenten uptake function as follows: $\%$ growth $\mathrm{IMP}^{-1}=18.00 \times[\mathrm{Chl}$ $a /(3.01+\mathrm{Chl} a)], r^{2}=0.68, n=25 . \mathrm{Vm}$ and Ks are constants representing, respectively, maximum growth and the $\mathrm{Chl} a$ concentration at which growth is half the maximum. Ks reflect the ability to grow at low food concentrations 

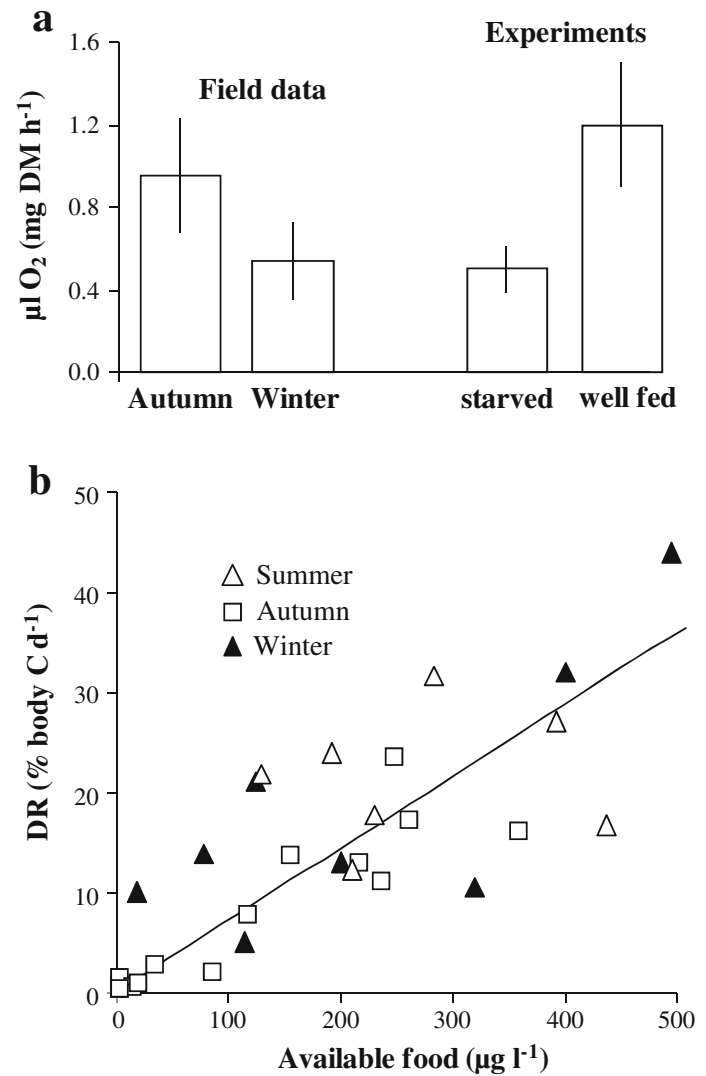

Fig. 10 Mean oxygen uptake rates of freshly caught furcilia larvae in autumn $(1999,2004)$ and winter (2006) in the Lazarev Sea and after one week starvation or exposure to high food concentrations in both seasons (a). Relationship between mean daily ration (DR) of furcilia larvae and available natural food assemblages from different regions and seasons (b). Summer data are from the WAP 2000, Marguerite Bay (Rothera Point, Meyer et al. 2003), Autumn data are from the Lazarev Sea 1999 and 2004 (Meyer et al. 2002a, b, 2009) and winter values are from the Lazarev Sea 2006 (Meyer et al. 2009) and unpublished data. The equation is as follows: $y=0.071 x, r^{2}=0.62, P<0.001$

Autumn and winter larvae showed a positive functional response in metabolic (Fig. 10a) and feeding activities (Fig. 10b) when exposed to increasing food concentrations (Meyer et al. 2002b, 2003, 2009). Winter larvae can have a daily food intake up to $500 \mu \mathrm{g} \mathrm{Cl}^{-1}$ (Fig. 10b) which corresponded to a Chl $a$ concentration of $10 \mu \mathrm{g} \mathrm{l}^{-1}$, a level not reached in the water column in the Southern Ocean in winter. These results suggest that the metabolic depression in winter larvae is a flexible adaptive behaviour to cope with the low food supply and that it is not an overwintering mechanism synchronised to the seasonal photoperiod as found in adult krill. The average oxygen uptake rates of winter larvae of $0.7 \mu \mathrm{O}_{2} \mathrm{mg} \mathrm{DW} \mathrm{h}^{-1}$ correspond to a daily energy demand of $0.0071 \mathrm{mg} \mathrm{C}$, which is equivalent to the weight of 1 Ctenocalanus sp., 2-3 Oithona sp. or 1-2 Oncea sp. Stomach content analysis of winter larvae from the Lazarev Sea has demonstrated that they are able to get

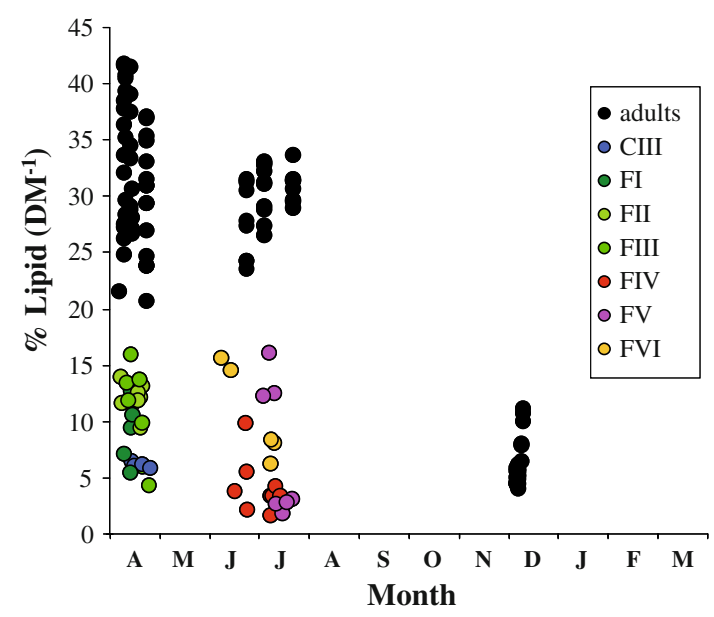

Fig. 11 Seasonal body lipid content of adult krill and their larval stages from the Lazarev Sea in late autumn (April), mid-winter (June, July) and late spring (November, December)

this amount of heterotropic diet in winter under sea ice (see below).

\section{Energy provision of larval krill during winter}

Larval krill were highly flexible in their energy provision during winter. In the Lazarev Sea, they utilised mainly body lipids and, to a moderate extent, body protein and were more heterotrophic than in summer and autumn (Meyer et al. 2009). On the other hand, studies done in the WAP region show a high pigment content in larval krill in winter and greenish coloured hepatopancreas, demonstrating the importance of autotrophic diet for winter larvae in this region (e.g. Frazer 1996; Frazer et al. 2002a; Quetin et al. 2007).

Body lipid utilisation and the ability to shrink Larvae, unlike adults, have no seasonal pattern in their lipid dynamic, and the same larval stages show a high inter and intra annual variability in their lipid levels (Deibel and Daly 2007; Ross and Quetin 1991) (Fig. 11, Table 8). In the Lazarev Sea, the average body lipid content in larvae increased with ontogenetic stage (CIII: $7 \%$, FI: $10 \%$, FII; III: $15 \% \mathrm{DM}^{-1}$ ), and hence, their tolerance to short starvation periods increases from days to a few weeks (Quetin and Ross 1991; Quetin et al. 1996; Daly 2004; Meyer and Oettl 2005; Meyer et al. 2009). In late autumn, the body lipid content of larval krill does not exceed $20 \%$ compared with $40 \%$ of total DM in adult krill.

Characteristic effects of starvation have been observed as changes in the ultra-structure of the digestive system, particularly the R (resorptive)-cells (Yoshida et al. 2009). After 5 days of starvation, Furcilia IV and V larvae showed an increase in the size of mitochondria and after 10-15 days 
Table 8 Body lipid content per dry mass (DM) in different ontogenetic stages of krill $(\mathrm{C}=$ calyptopis, $\mathrm{F}=$ furcilia $)$ and different regions

\begin{tabular}{llllll}
\hline Season & Larval stages & Lipid $\left(\% \mathrm{DM}^{-1}\right)$ & Region & Month and year & References \\
\hline Mid summer & CI,II & $12.3 \pm 1.4(8)$ & Weddell Sea & Jan-Feb 1986 & Hagen et al. (2001) \\
& CIII & $15(1)$ & Weddell Sea & Apr-May 1992 & Meyer et al. (2009) \\
Late autumn & CIII & $6.6 \pm 0.1(5)$ & Lazarev Sea & Apr-May 2004 & Apr-May 1999 \\
& FI-FIII & $12.4 \pm 2.2(14)$ & & & Meyer et al. (2002a) \\
& FIII & $15.5 \pm 4.3(18)$ & & Apr-May 1992 & Hagen et al. (2001) \\
Winter & FI-FIV & $18.4 \pm 5.4(12)$ & Weddell Sea & July 2006 & Meyer et al. (2009) \\
Mid spring & FIV-FVI & $7.4 \pm 3.8(19)$ & Lazarev Sea & Oct-Nov 1986 & Hagen et al. (2001) \\
& FV & $7.3 \pm 1.6(2)$ & Lazarev Sea & Oct-Nov 1983 & \\
\hline
\end{tabular}

Number of replicates in brackets. Modified according to Deibel and Daly (2007)

of starvation, a thickened basal lamina with irregular infoldings. The R-cells with swollen mitochondria and thickened basal lamina appear to lose their ability to take up food. At this stage, the larvae loose their capability to recover from nutritional stress. The Point of No Return (PNR) is reached. These observations and the average lipid content of larvae imply that, unlike adults, no larval stage could survive several months without food, indicating that larval survival is dependent on both the amount of lipid reserves as well as the food supply during winter.

Shrinkage of krill larvae has so far only been reported in some studies in the WAP region (Ross and Quetin 1991; Quetin et al. 2003; Ross et al. 2004). In the Lazarev Sea, shrinkage was observed at only one station in a few individuals (Meyer et al. 2009) and was always related to very low lipid levels of the larvae $\left(\leq 5 \% \mathrm{DM}^{-1}\right)$. These results suggest that, similar to adult krill, shrinkage is the exception rather than the rule in larvae and that it is an indicator of severe physiological condition.

The utilisation of body protein and the importance of heterotrophic diet for winter larvae In addition to the utilisation of body lipids, krill larvae utilised protein at moderate rates. A comprehensive data set from the Lazarev Sea (stomach and gut content, ammonium production rates, $\mathrm{O}: \mathrm{N}$ ratio, relationship between $\mathrm{N}$ and protein and $\mathrm{DW}$ and $\mathrm{N}$ ) has demonstrated that heterotrophic diet plays an important role in winter, whereas in autumn, algae are more important food (Meyer et al. 2009; Töbe et al. 2010). Several studies have demonstrated that heterotrophic organisms are more abundant under sea ice in winter than in autumn (Tanimura et al. 1986; Garrison and Close 1993; Schnack-Schiel et al. 2001). In the Lazarev Sea, a high abundance of Oithona spp. was associated with larval krill between rafted sea ice floes, and it was observed that the larvae made use of them (Meyer et al. 2009; Töbe et al. 2010). In contrast, autotrophic diet seems to be important for winter larvae in the WAP region (e.g. Frazer 1996; Frazer et al. 2002a; Quetin et al. 2007).

The moderate consumption of body protein and the utilisation of protein-rich diet, as well as the utilisation of lipids, indicate a flexibility of larval krill in their source of energy during winter.

\section{The role of sea ice for overwintering success of larval krill}

Unlike adults, larvae have to find food continuously to meet their energetic needs. High abundances of larvae have regularly been observed associated with the sea ice in winter (Marr 1962; Guzmán 1983; Kottmeier and Sullivan 1987; Daly 1990; Daly and Macaulay 1991; Quetin et al. 1996; Frazer et al. 1997, 2002b, Ross et al. 2004; Meyer et al. 2009) and in regions with over-rafted ice floes (Frazer et al. 1997, 2002b; Ross et al. 2004; Meyer et al. 2009). Due to under-ice topography and its influence on current speed, larvae as well as their planktonic prey can aggregate and rest in these rafted ice refuges (Meyer et al. 2009). Sea ice biota can be released by floe movements within these refuges, (Tanimura et al. 2008), resulting in favourable feeding condition for larval krill. SCUBA observations in the WAP region and the Lazarev Sea saw the majority of larvae on the "floors" of the rafted ice refuges (e.g. Quetin et al. 1996; Frazer 1996; Meyer et al. 2009).

In an environment with high current speeds, ice refuges might be essential for resting and feeding of krill larvae in seasons of low food availability in the water column. Overwintering studies of larval krill in different regions have demonstrated that ice-related larvae are in much better condition than those from open water areas (Ross and Quetin 1991; Daly 2004; Meyer et al. 2009).

Our understanding of larval krill in winter comes from a small number of studies, mainly performed in the WAP region and the Lazarev Sea, which make it difficult to generalise the observations that winter sea ice might be 
essential for a successful development of larval krill and consequently the recruitment success of krill. Both regions are very different in their environmental characteristics. The WAP region is characterised by a wide shelf, high primary productivity and profound environmental changes. The Lazarev Sea represents an open oceanic region of the eastern Weddell Sea. The continent shelf is narrow, the majority of krill live in the ocean region, where water depths exceed 4,000 $\mathrm{m}$ and primary productivity is highly variable (Meyer et al. 2010). In contrast to the WAP, the winter ice cover of the Lazarev Sea has not changed since 1979 or has slightly increased (Parkinson 2004). However, the physiological conditions of larvae from these different regions reveal the importance of specific biological and physical winter sea ice condition for successful development during winter. This seems to apply also for larvae which spawned in the almost year-round ice-free waters around South Georgia and the Northern Scotia Sea. The Lagrangian circulation model reported by Thorpe et al. (2007) suggested that larval krill, spawned in the Northern Scotia Sea offshore in the Southern Antarctic Circumpolar Current Front (SACCF), could be transported to the eastern Weddell Sea for overwintering. This region is almost unaffected by the recent reduction in sea ice cover and is therefore a suitable habitat for larval krill overwintering.

\section{Annual life cycle in changing Southern Ocean environment}

\section{The critical winter period}

The seasonal data on krill's physiological activity, elemental and biochemical composition have documented that the species has a successful and complex life cycle adapted to the highly seasonal environment of the Southern Ocean. Seasonal growth and reproductive cycles of krill are synchronised with seasonal cycles of food supply and photoperiod. Food availability has been identified as the most critical factor in krill's life cycle (e.g. Siegel 2005; Atkinson et al. 2008; Meyer et al. 2009, 2010). In early spring, a well-developed sea ice microbial community and/or the timing of a well-developed spring phytoplankton bloom seem to be a prerequisite for successful recruitment enabling early ovarian development, early spawning and multiple egg batches (Quetin and Ross 2001, Schmidt et al. 2011b). This, in turn, enhances subsequent larval survival and development as well as enhancing the physiological condition of adults in preparation for the following winter. Larvae that hatched early are most likely in a better condition for a successful development and survival during winter than larvae from late spawning krill because they enter the winter season at an advanced stage with sufficiently high lipid reserves (Pakhomov et al. 2004; Meyer et al. 2009). During summer, favourable feeding conditions enable adult krill to accumulate a large lipid store to sustain the winter season and enable even larvae from late spawned krill to enter the winter season in an advanced stage. Large lipid stores at the onset of winter might also promote external maturation (thelycum development) during winter and internal maturation (early ovarian development) in early spring, even in years when phytoplankton bloom is delayed (Teschke et al. 2008). In autumn, timing of sea ice formation is crucial, since the earlier sea ice forms, the more algal biomass are usually incorporated (Fritsen et al. 2008). Moreover, earlier ice formation means greater total light availability for the ice algae to grow before mid-winter (when light levels are mostly too low for primary production) (Smith et al. 2008; Fritsen et al. 2011). By midautumn, metabolic activity of adult krill is reduced, most likely influenced by changes in photoperiod, and this is accompanied by a reduction in feeding activity and growth (Meyer et al. 2010).

Krill larvae have to feed during winter to meet their metabolic demands and to grow successfully to juveniles in the following spring. Sea ice provides a nutrient-rich substrate on and within which a microbial community can develop. The small brine channels within the sea ice serve as drainage routes, transporting a large amount of organic material into the underlying sea water. This provides a substrate for microbial growth, which acts, in turn, as food source for invertebrates associated with the underlying sea ice surface (Menshenina and Melnikov 1995; Melnikov 1998; Thomas and Dieckmann 2003). Furthermore, in early spring, the microalgae that grow within the sea ice provide a seeding effect for the development of open ocean blooms in spring.

Recruitment success depends on a series of critical stages in krill's life cycle. The first critical stage is the intensity of spawning output of adult krill in early spring, which is favoured by "superfluous" feeding at high diatom concentrations and the absorption of crucial fatty acids from diatoms (Schmidt et al. 2011b). In addition in the first year of krill's life, the larvae have to successfully pass through three potentially critical stages to ensure good juvenile recruitment in subsequent spring (Ross and Quetin 1991). The first feeding stage of krill (Calyptopis I), which reaches the surface water after the developmental ascent, has to find food within the first 10 days to enable further development (Ross and Quetin 1989). The next critical stage is determined by food availability during summer and autumn to enable the larvae to develop to an advanced stage with sufficient lipid reserves until the onset of winter. The last important step for a large recruitment output in the following spring is the survival of larvae during the winter season.

A conceptual model has been developed that links recruitment success to the timing of seasonal sea ice events 
mediated through availability of food for larvae (Siegel and Loeb 1995; Quetin et al. 1996, 2007; Quetin and Ross 2009). This concept was developed from investigations on krill in the WAP area but is well supported by data from krill studies in the high sea region of the Lazarev Sea (Meyer et al. 2009).

The warming at the Antarctic Peninsula and the effect of the krill stock in the SW Atlantic sector

The Antarctic Peninsula region is a hot spot for krill research for two reasons: Firstly, the area is in addition to the Scotia Sea important for krill recruitment in the SW Atlantic sector of the Southern Ocean and; secondly, it is currently experiencing a rapid regional climate change, with profound impacts on the marine environment.

The WAP region is one of the most rapidly warming regions on Earth, having experienced a $2^{\circ} \mathrm{C}$ increase in the annual mean air temperature since 1950 (Drinkwater Ducklow et al. 2007), with the most profound air temperature rise in winter $\left(6^{\circ} \mathrm{C}\right.$ in mean since 1950). The surface summer temperature of the adjacent ocean has warmed by more than $1^{\circ} \mathrm{C}$ (Meredith and King 2005). This warming trend affects the seasonal sea ice dynamics in this region. Satellite data reveal a 20\% decline in sea ice extent in the Amundsen and Bellingshausen Seas in the two decades following 1973 (Jacobs and Comiso 1997). The seasonality of the regional sea ice cover has changed during the last 40 years, particularly waters off the northeast and west Antarctic Peninsula and southern Bellingshausen Sea. Whereas in the late 1970s, sea ice advance was mainly in March, this has shifted to April or May at present and sea ice retreat started in some years as early as July/August instead of September/ October (Parkinson 2004, Stammerjohn et al. 2008). This translates into a much shorter duration of the annual sea ice season, which will have a direct impact on the marine biota, that rely on the microbial sea ice community (Clarke et al. 2007).

There is little information on biological responses to climate change in Antarctica, due to the lack of sufficiently long ecological data series. Fortunately, the distribution and abundance of krill have been intensively studied for nearly 90 years. Recently, a major reduction in krill abundance has been reported for the Scotia Sea sector of the SW Atlantic region during the period of 1976-2004, derived from net surveys between the 1920s and present (Atkinson et al. 2004). During the same time span, another study showed considerable fluctuations in krill biomass in the WAP region and Scotia Sea rather than a major reduction (Trivelpiece et al. 2011), and yet another did not see a clear krill decline in the WAP region due to episodic recruitment (Ross et al. 2008), that leads to a 5-6 year cycle in the abundance of krill (Quetin and Ross 2003). Over a shorter period (1991-2004), krill densities, estimated by acoustics at the northern tip of the Peninsula, suggest a cycle in krill abundance (Hewitt et al. 2003). In general, determining trends in krill abundance is difficult due to spatial and temporal sampling constraints that under-sample cyclical population swings caused by recruitment variability (Quetin and Ross 2003; Smetacek and Nicol 2005). However, the longterm decline of the krill stock over the last 30 years, reported by Atkinson et al. (2004), has been correlated with both the duration and the extent of sea ice during the previous winter in the same area. This result suggests that the fluctuations are driven by recruitment, rather than by predation pressure on adult krill. The suggested declining trend of krill abundance in the SW Atlantic sector will be discussed later on in context with energetic demands of larval krill during winter.

Various mechanisms, as outlined previously, have been proposed to explain how sea ice benefits krill. Timing and latitudinal range of sea ice formation seem to be key for a well-developed sea ice microbial community. However, the ongoing warming trend at the WAP region has caused a more frequent miss-match in timing of the occurrence of high phytoplankton concentrations in the water column and the start of sea ice formation (Smith et al. 2008). Sea ice formation in the WAP region in April resulted in a tenfold higher Chl $a$ content of the sea ice compared with late formation end of June (Fritsen et al. 2008). Furthermore, the shorter the sea ice duration during winter, the thinner and more un-deformed is the ice. In contrast, a long sea ice duration results in thicker and more rafted ice (Massom and Stammerjohn 2010), providing better feeding refuges for larval krill (Meyer et al. 2009). The long-term data set on krill from the Palmer-LTER program provided preliminary evidence that populations of krill are declining in concert with an increasing delay in sea ice advance (Ross et al. 2008).

The WAP area and Scotia Sea are considered to be the major spawning and nursery areas of krill (Marr 1962; Quetin et al. 1996; Siegel 2000; Hoffmann and Hüsrevoglu 2003; Thorpe et al. 2007, Schmidt et al. 2011b). Therefore, due to the energetic demands of larval krill outlined in this review, a shift in the seasonal sea ice dynamic, mainly observed in the WAP region, will most likely effect growth and development success of larvae during winter and consequently the krill stock in the SW Atlantic sector of the Southern Ocean.

The reduced winter sea ice cover in the WAP region may be accompanied by increased predation and harvesting of krill year round (Kawaguchi et al. 2009). The Antarctic Peninsula is the region where the krill fishery and the highest abundance of krill predators around Antarctica are concentrated (Kock et al. 2007). If this area becomes perennially ice free, then depredation of krill stocks by air 
breathing vertebrates and fishing fleets will be possible year round and might result in a reduction in krill productivity. Krill fishing has already started to increase as a result of the increasing economic interest in high value krill products (Nicol 2011).

In parallel with the warming, the maritime system of the northern WAP is shifting southward along the Antarctic Peninsula, replacing the colder continental polar system of the southern WAP (Smith et al. 2003). As a consequence due to an ongoing warming trend in the WAP region, a possible migration of krill from lower (e.g. Northern WAP region) to higher latitudes such as Bellingshausen and Amundsen Seas implicates profound changes in the seasonal course of the photoperiod that krill experience (Fig. 1). As a result of the shorter photoperiod and a low sun angle during autumn/winter at higher latitudes, significantly less light reaches the water/sea ice surface for phytoplankton growth and productivity than at lower latitudes influencing the intensity of primary production in the water column and within sea ice when it is formed. This is crucial to the autotrophic food availability for larval krill during winter (Quetin et al. 2007). On the other hand, a longer sea ice duration at higher latitudes might guarantee more over-rafted sea ice refuges with favourable feeding conditions for larvae on a heterotrophic diet as already discussed. This might compensate for the low phytoplankton biomass within sea ice. As outlined previously, photoperiod seems to act as an important factor influencing physiological functions in adult krill. An endogenous timing rhythm in krill can be a disadvantage when krill may be restricted by latitude. Previously matched interactions between krill's endogenous seasonal physiological rhythms (e.g. maturation) and environmental cycles (e.g. seasonal sea ice dynamic) may go out of phase. The warming in the WAP region seems to result in late sea ice development and earlier retreat, consequently influencing the timing of the phytoplankton spring bloom. Hence, krill might not be able to meet their high energetic needs after their metabolic winter depression in spring for maturation and spawning processes, which consequently effecting the population. This scenario highlights the importance of understanding the cues that are related and unrelated to environmental changes to time krill's annual cycle and which physiological functions are mediated during krill's ontogeny by these cues.

Predicting of changes in the Southern Ocean pelagic ecosystem

Krill control population and community dynamics and modulate ecosystem processes in the Southern Ocean. Due to their central position in a "wasp-waist" ecosystem (Bakun 2006), their decline would chronically impact biological fluxes of energy and nutrients in the Southern Ocean. The ultimate loss of krill would change the biodiversity of the Southern Ocean and would potentially disrupt fundamental ecosystem processes, including rates of decomposition, nutrient fluxes, carbon sequestration and energy flow. A critical point here is that we need to progress beyond correlative studies towards a mechanistic understanding of the system. In this respect, from the perspective of the present review, critical areas for future research will be highlighted below.

Despite the importance of krill in the Southern Ocean ecosystem and almost 90 years of krill research, we are unable to predict whether krill will be able to adapt fast enough to keep up with their changing environment (e.g. dispersal to suitable habitats elsewhere, changes in the phenotype: i.e. morphology, development, biochemical or physiological properties, or behaviour, genetic change: i.e. microevolution). For evaluating the performance of krill, it is essential to understand the cues that are related and unrelated (e.g. timing of phytoplankton spring bloom and photoperiod, respectively) to climate-induced environmental changes and their impact on krill's annual cycle and timing of maturation, spawning, lipid accumulation and metabolic activity. As mentioned above, the ongoing environmental changes in the Southern Ocean might upset the balance between krill's endogenous rhythms and its environment with profound consequences to the whole ecosystem. Our current understanding of biological rhythms and clocks is largely restricted to solar-controlled circadian and seasonal rhythms in terrestrial model species such as the fruitfly, the mouse or the thale cress (Tessmar-Raible et al. 2011). Recently, Mazotta et al. (2010) identified a cryptochrome gene in krill, which is a cardinal component of the clockwork machinery in several terrestrial organisms, whereas Teschke et al. (2011) found additional evidence for a circardian clock in adult krill, which governs metabolic output rhythms. However, it is currently far from clear which physiological functions are mediated by the endogenous clock in krill and what are the associated molecular mechanisms during the annual cycle and during krill's ontogeny. Future studies are required to characterise the circardian/ circannual clock in krill and to unravel the role of an endogenous timing system in the rhythmic and synchronised daily and seasonal behaviours of krill. In studying the adaptation of krill to a changing environment, we need to consider the functional integration of single molecules into higher organisational levels, up to the whole organism as well as its evolutionary genetic history. Results from both, the studies on evolutionary history and the actual response mechanisms of krill to environmental changes on an organismic, cellular and molecular level provide information as to how these species have adapted to their current accommodation to the environment.

Most studies on krill focus on adult specimens. To understand the sensitivity of a species to climate change, 
however, it is important to take the entire life cycle into account when predicting future shifts. A vital step in successful krill recruitment is survival through the first winter. It is not clear which sea ice conditions are essential for a successful development of larvae during winter (e.g. abundance of heterotroph or autotroph microbioal community, rafted sea ice refuges, duration of sea ice cover). However, this knowledge is essential to predict trends in krill abundance and possible ecosystem shifts. To overcome these uncertainties, krill abundance, distribution and condition have to be investigated in relation to environmental conditions (e.g. food quality and quantity, current speed, sea ice thickness, under sea ice topography) in regions with different seasonal sea ice dynamics (WAP, South Georgia region, Scotia-Weddell Sea, East Antarctica). A consistent multi-analytical approach has to be used to ensure comparability of data. Due to the limitation of net-based sampling during winter, larval krill sampling and sampling of potential food organisms under sea ice as well as under sea ice observations via SCUBA are required. In addition, the use of latest ROV technology with optical sensors including an upward-looking radiometer, upward-looking sonar and accurate depth sensor are necessary to predict sea ice algal biomass in large-scale surveys.

For reliable predictions of potential changes of the marine pelagic ecosystem of the Southern Ocean, models have to be built on a far more robust functional understanding of the linkage between organisms and their environment. Therefore, long-term environmental data and the abundance of krill have to be combined with data from process-oriented studies on the performance of adult and larval krill, as outlined above. This will allow testing different scenarios of environmental changes and consequences for the population dynamic of krill. Future projects should aim to advance our ability to determine the resilience and susceptibility of ecosystems to environmental changes and human influences (such as harvesting). Given that Antarctic ecosystems are exceptionally vulnerable to large-scale changes and human influence, it is imperative that we understand the nature and complexity of the potential future changes induced by climate change. Due to the key position of Antarctic krill (Euphausia superba) in the Southern Ocean, this species can act as a model organism for studying the impact of climate change on biodiversity, biogeochemical cycles and food web processes in the Southern Ocean and to understand the performance of polar pelagic invertebrates to climate-induced environmental changes.

Acknowledgments My special thanks go to Lutz Auerswald, Gottfried Hempel, Steve Nicol, Mathias Teschke, Angus Atkinson, and So Kawaguchi for their critical reading of the review and the fruitful discussions we had and the constructive comments of two anonymous referees. The work done in my group was funded by the German Ministry of Education and Research (BMBF) through projects
03PL025A and 03F0400A, the International Bureau of the BMBF through projects ARG 02/Z01 and SUA 05/008. In this respect, I also want to thank the officers and crew of RV "Polarstern" for their professional support on all cruises (ANTVI-3, ANTXVIII-5b, ANTXXI-4, ANTXXIII-2, ANTXXIII-6) and the diving team under the direction of Ulrich Freier. My special thanks go also to Susanne Spahić for her technical support in my group. My gratitude extents to the colleges, graduate-, and undergraduate students who contributed to this work.

Open Access This article is distributed under the terms of the Creative Commons Attribution Noncommercial License which permits any noncommercial use, distribution, and reproduction in any medium, provided the original author(s) and source are credited.

\section{References}

Atkinson A, Meyer B, Stübing D, Hagen W, Bathmann UV (2002) Feeding and energy budgets of Antarctic krill Euphausia superba at the onset of winter-II. Juveniles and adults. Limnol Oceanogr 47:953-966

Atkinson A, Siegel V, Pakhomov EA, Rothery P (2004) Long-term decline in krill stock and increase in salps within the Southern Ocean. Nature 432:100-103

Atkinson A, Shreeve RS, Hirst AG, Rothery P, Tarling GA, Pond DW, Korb RE, Murphy EJ, Watkins JL (2006) Natural growth rates in Antarctic krill (Euphausia superba): II: Predictive models based on food, temperature, body length, sex, and maturity stage. Limnol Oceanogr 51:973-987

Atkinson A, Siegel V, Pakhomov EA, Rothery P, Loeb V, Ross RM, Quetin LB, Schmidt K, Fretwell P, Murphy EJ, Tarling GA, Fleming AH (2008) Oceanic circumpolar habitats of Antarctic krill. Mar Ecol Prog Ser 362:1-23

Bakun A (2006) Wasp-waist populations and marine ecosystem dynamics: Navigating the "predator pit" topographies. Prog Oceanogr 68:271-288

Bergström BI, Hempel G, Marshall HP, North A, Siegel V, Strömberg JO (1990) Spring distribution, size composition and behaviour of krill Euphausia superba in the western Weddell Sea. Polar Record 26:85-89

Brett JR, Groves TDD (1979) Physiological energetics. In: Hoar WS, Randall DJ, Brett JR (eds) Fish Physiology, 8rd edn edn. Academic Press, New York, pp 280-352

Brierley AS, Watkins JL (2000) Effects of sea ice cover on the swarming behaviour of Antarctic krill, Euphausia superba. Can J Fish Aquat Sci 57:24-30

Brierley AS, Fernandes PG, Brandon MA, Armstrong F, Millard NW, McPhail SD, Stevenson P, Pebody M, Perrett J, Squres M, Bone DG, Griffiths G (2002) Antarctic krill under sea ice: Elevated abundance in a narrow band just south of ice edge. Science 295:1890-1892

Brinton E, Townsend AW (1984) Regional relationships between development and growth in larvae of Antarctic krill, Euphausia superba, from field samples. J Crust Biol 4:224-246

Brown M, Kawaguchi S, Candy S, Virtue P (2010) Temperature effects on the growth and maturation of Antarctic krill (Euphausia superba). Deep-Sea Res II 57:672-682

Buchholz F (1989) Moult cycle and seasonal activities of chitinolytic enzymes in the integument and digestive tract of the Antarctic krill, Euphausia superba. Polar Biol 9:311-317

Buchholz F, Morris DJ, Watkins JL (1989) Analyses of field moult data: prediction of intermoult period and assessment of seasonal growth in Antarctic krill, Euphausia superba Dana. Antarct Sci 1:301-306

Clarke A, Morris DJ (1983) Towards an energy budget for krill: the physiology and biochemistry of Euphausia superba Dana. Polar Biol 2:69-86 
Clarke A, Tyler PA (2008) Adult Antarctic krill feeding at abyssal depth. Current Biol 18:282-285

Clarke A, Murphy EJ, Meredith MP, King JC, Peck LS, Barnes DKA, Smith RC (2007) Climate change and the marine ecosystem of the western Antarctic Peninsula. Phil Trans R Soc B 362:149-166

Cuzin-Roudy J, Labat JP (1992) Early summer distribution of Antarctic krill sexual development in the Scotia-Weddell region: a multivariate approach. Polar Biol 12:65-74

Daly KL (1990) Overwintering development, growth, and feeding of larval Euphausia superba in the Antarctic marginal ice zone. Limnol Oceanogr 35:1564-1576

Daly KL (2004) Overwintering growth and development of larval Euphausia superba an interannual comparison under varying environmental conditions west of the Antarctic Peninsula. DeepSea Res II 51:2139-2168

Daly KL, Macaulay MC (1991) Influence of physical and biological mesoscale dynamics on the seasonal distribution and behaviour of Euphausia superba in the Antarctic marginal ice zone. Mar Ecol Prog Ser 79:37-66

Deibel D, Daly KL (2007) Zooplankton of the Southern Ocean. In: Smith WO, Barber DG (eds) Zooplankton processes in Arctic and Anatrctic Polynyas, Chapter 9. Elsevier Oceanogr Ser 74:287322

Donnelly J, Kawall H, Geiger SP, Torres JJ (2004) Metabolism of Antarctic micronektonic crustacean across a summer ice-edge bloom: respiration, composition, and enzymatic activity. Deep-Sea Res II 51:2225-2245

Drinkwater Ducklow HW, Baker K, Martinson DG, Quetin LB, Ross RM, Smith RC, Stammerjohn SE, Vernet M, Fraser W (2007) Marine pelagic ecosystems: the West Antarctic Peninsula. Phil Trans Soc B 362:67-94

Ettershank G (1983) Age structure and cyclical annual size change in the Antarctic krill, Euphausia superba Dana. Polar Biol 2:189-193

Everson I (1977) The living resources of the Southern Ocean. FAO Southern Ocean Fisheries Survey Programme, GLO/SO/77/1. pp $1-156$

Feinberg LR, Shaw CT, Peterson WT (2006) Larval development of Euphausia pacifica in the laboratory: variability in developmental pathways. Mar Ecol Prog Ser 316:127-137

Flores H, van Franeker J-A, Cisewski B, Leach H, Van de Putte AP, Meesters E, Bathmann U, Wolf WJ (2011) Macrofauna under sea ice and in the open surface layer of the Lazarev Sea, Southern Ocean. Deep-Sea Res II. doi:10.1016/j.dsr2.2011.01.010

Frazer TK (1996) Stable isotope composition $\left(\delta^{13} \mathrm{C}\right.$ and $\left.\delta^{15} \mathrm{~N}\right)$ of larval krill, Euphausia superba, and two of its potential food sources in winter. J Plankton Res 18:1413-1426

Frazer TK, Quetin LB, Ross RM (1997) Abundance and distribution of larval krill, Euphausia superba, associated with annual sea ice in winter. In: Battaglia B, Valencia J, Walton DWH (eds) Antarctic communities: Species. structure and survival. University Press, Cambridge, pp 107-111

Frazer TK, Quetin LB, Ross RM (2002a) Energetic demands of larval krill, Euphausia superba, in winter. J Exp Mar Biol Ecol 277:157-171

Frazer TK, Quetin LB, Ross RM (2002b) Abundance, sizes and developmental stages of larval krill, Euphausia superba, during winter in ice-covered seas, west of the Antarctic Peninsula. J Plankton Res 24:1067-1077

Fritsen CH, Memmott JC, Stewart FJ (2008) Inter-annual sea-ice dynamics and micro-algal biomass in winter pack ice of Marguerite Bay, Antarctica. Deep-Sea Res II 55:2059-2067

Fritsen CH, Memmott JC, Ross RM, Quetin LB, Vernet M, Wirthlin ED (2011) The timing of sea ice formation and exposure to photosynthetically active radiation along the Western Antarctic Peninsula. Polar Biol 34:683-692
Garrison DL, Close AR (1993) Winter ecology of the sea ice biota in Weddell Sea pack ice. Mar Ecol Prog Ser 96:17-31

Gaten E, Tarling G, Dowse H, Kyriacou C, Rosato E (2008) Is vertical migration in Antarctic krill (Euphausia superba) influenced by an underlying circadian rhythm? J Genet 87:473-483

Gillooly JF, Brown JH, West GB, Savage VM, Charnov EL (2001) Effects of size and temperature on metabolic rates Science 293:2248-2251

Gutt J, Siegel V (1994) Benthopelagic aggregations of krill (Euphausia superba) on the deeper shelf of the Weddell Sea (Antarctic). Deep-Sea Res I 41:169-178

Guzmán O (1983) Distribution and abundance of Antarctic krill (Euphausia auperba) in the Bransfield Strait. Ber Polarforsch 4:169190

Hagen W, Kattner G, Terbrüggen A, Van Vleet ES (2001) Lipid metabolism of the Antarctic krill Euphausia superba and its ecological implications. Mar Biol 139:95-104

Hamner WM, Hamner PP, Strand SW, Gilmer RW (1983) Behavior of Antarctic krill Euphausia superba: Chemoreception, Feeding Schooling, Molting. Science 220:433-435

Hempel I (1985) Variation in geographical distribution and abundance of larvae of Antarctic krill Euphausia superba in the Southern Atlantic Ocean. In: Sigfried WR, Condy RR, Laws RM (eds) Antarctic nutrient cycles and food webs. Springer, Berlin, pp 308310

Hempel G (1987) Cruise leg ANT V/3 Cape Town-Cape Town. In: Schnack-Schiel (ed) The winter-expedition of RV "Polarstern" to the Antarctic (ANT V/1-3). Ber Polarforsch 39, pp 127-249

Hewitt RP, Demer DA, Emery JH (2003) An 8-year cycle in krill biomass density inferred from acoustic surveys conducted in the vicinity of the South Shetland Islands during the austral summers of 1991-1992 through 2001-2002. Aquat Liv Res 16:205-213

Hoffmann EE, Hüsrevoglu YS (2003) A circumpolar modeling study of habitat control of Antarctic krill (Euphausia superba) reproductive success. Deep-Sea Res II 50:3121-3142

Hopkins TL, Torres JJ (1989) Midwater food web in the vicinity of a marginal ice zone in the western Weddell Sea. Deep-Sea Res 36:543-560

Hopkins TL, Lancraft TM, Torres JJ, Donelly J (1993) Community structure and trophic ecology of zooplankton in the Scotia Sea marginal ice zone in winter (1988). Deep-Sea Res I 40:81-105

Huntley M, Nordhausen W, Lopez MDG (1994) Elemental composition, metabolic activity and growth of Antarctic krill Euphausia superba during winter. Mar Ecol Prog Ser 107:23-40

Ikeda T (1981) Metabolic activity of larval stages of Antarctic krill. Antarct J US 16:161-162

Ikeda T, Dixon T (1982) Body shrinkage as a possible overwintering mechanism of the Antarctic krill, Euphausia superba Dana. J Exp Mar Biol Ecol 62:143-151

Ikeda T, Mitchell AW (1982) Oxygen uptake, ammonia excretion and phosphate excretion by krill and other Antarctic zooplankton in relation to their body size and chemical composition. Mar Biol $71: 283-298$

Jacobs SS, Comiso JC (1997) Climate variability in the Amundsen and Bellingshausen Seas. J Clim 24:697-709

Kawaguchi K, Ishikawa S, Matsuda O (1986) The overwintering strategy of Antarctic krill (Euphausia superba Dana) under the coastal fast ice off the Ongul Islands in Lützow-Holm Bay, Antarctica. Mem Nat Inst Polar Res Spec Iss 44:67-85

Kawaguchi S, Ichii T, Naganobu M (1999) Green krill, the indicator of micro- and nano-size phytoplankton availability to krill. Polar Biol 22:133-136

Kawaguchi S, Candy SG, King R, Naganobu M, Nicol S (2006) Modelling growth of Antarctic krill. I. Growth trends with sex, length, season, and region. Mar Ecol Prog Ser 206:1-15 
Kawaguchi S, Yoshida T, Finley L, Cramp P, Nicol S (2007) The krill maturity cycle: a conceptual model of the seasonal cycle in Antarctic krill. Polar Biol 30:689-698

Kawaguchi S, Nicol S, Press AJ (2009) Direct effects of climate change on the Antarctic krill fishery. Fish Manage Ecol 16:424-427

Kawaguchi S, Kilpatrick R, Roberts L, King R, Nicol S (2011) Oceanbottom krill sex. J Plank Res doi:10.1093/plankt/fbr006

Knox AG (1994) The biology of the Southern Ocean. In: Clarke A, Bliss L, Dewry DJ, Walton DWH, Williams PJ (eds) Studies in polar research. Cambridge University Press, Cambridge

Kock KH, Reid K, Croxall J, Nicol S (2007) Fisheries in the Southern Ocean: an ecosystem approach. Philosoph Transact Royal Soc B 362:2333-2349

Kottmeier ST, Sullivan CW (1987) Late winter primary production and bacterial production in sea ice and seawater west of the Antarctic Peninsula. Mar Ecol Prog Ser 36:287-298

Lancraft TM, Hopkins TL, Torres JJ, Donelly J (1991) Oceanic micronektonic/macrozoo-planktonic community structure and feeding in ice covered Antarctic waters during winter (AMERIEZ 1988). Polar Biol 11:157-167

Lascara CM, Hofman EE, Ross RM, Quetin LB (1999) Seasonal variability in the distribution of Antarctic krill. Euphausia superba, west of the Antarctic Peninsula. Deep-Sea Res I 46:951-984

Lawson GL, Wiebe PH, Ashjian CJ, Stanton TK (2008) Euphausiid distribution along the Western Antarctic Peninsula-Part B: Distribution of euphausiid aggregations and biomass, and associations with environmental features. Deep-Sea Res II 55:432-454

Le-Fevre J, Legendre L, Rivkin RB (1998) Fluxes of biogenic carbon in the Southern Ocean: roles of large microphagous zooplankton. J Mar Syst 17:325-345

Ligowski R (2000) Benthic feeding by krill, Euphausia superba Dana, in coastal waters off West Antarctica and in Admiralty Bay, South Shetland Islands. Polar Biol 23:619-625

Loeb V, Siegel V, Holm-Hansen O, Hewitt R, Fraser W, Trivelpiece W, Trivelpiece S (1997) Effects of sea-ice extent and krill or salp dominance on the Antarctic food web. Nature 387:897-900

Mackintosh NA (1972) Life cycle of Antarctic krill in relation to ice and water conditions. Discovery Rep 36:1-94

Marin VH, Brinton E, Huntley M (1991) Depth relationships of Euphausia superba eggs, larvae and adults near the Antarctic Peninsula, 1986-1987. Deep-Sea Res 38:1241-1249

Marr JWS (1962) The natural history and geography of the Antarctic krill (Euphausia superba Dana). Discovery Rep 32:33-464

Marschall HP (1988) The overwintering strategy of Antarctic krill under pack-ice of the Weddell Sea. Polar Biol 9:245-250

Massom RA, Stammerjohn SE (2010) Antarctic sea ice change and variability-Physical and ecological implications. Polar Sci 4:138

Mazzotta GM, De Pittà C, Benna C, Tosatto SCE, Lanfranchi G, Bertolucci C, Bertolucci C (2010) A CRY from the krill. Chronobiol 27:425-445

McClatchie S (1988) Food-limited growth of Euphausia superb in Admiralty Bay, South Shetland Islands, Antarctica. Cont Shelf Res 8:329-345

Melnikov IA (1998) Winter production of sea ice algae in the western Weddell Sea. J Mar Syst 17:195-205

Menshenina L, Melnikov IA (1995) Under-ice zooplankton of the western Weddell Sea. Proc NIPR Symp Polar Biol 8:126-138

Meredith MP, King JC (2005) Rapid climate change in the ocean west of the Antarctic Peninsula during the second half of the 20th century. Geophys Res Lett 32:L19604. doi:10.1029/2005GL024042

Meyer B, Oettl B (2005) Effects of short-term starvation on composition and metabolism of larval Antarctic krill, Euphausia superba. Mar Ecol Prog Ser 292:263-270

Meyer B, Saborowski R, Atkinson A, Buchholz F, Bathmann U (2002a) Seasonal differences in citrate synthase and digestive activity in larval and postlarval Antarctic krill, Euphausia superba. Mar Biol 141:855-862

Meyer B, Atkinson A, Stübing D, Oettl B, Hagen W, Bathmann UV (2002b) Feeding and energy budgets of Antarctic krill Euphausia superba at the onset of winter-I-Furcilia III larvae. Limnol Oceanogr 47:943-952

Meyer B, Atkinson A, Blume B, Bathmann UV (2003) Feeding and energy budgets of larval Antarctic krill, Euphausia superba, in summer. Mar Ecol Prog Ser 257:167-178

Meyer B, Fuentes V, Guerra C, Schmidt K, Atkinson A, Spahic S, Cisewski B, Freier U, Olariaga A, Bathmann U (2009) Physiology, growth and development of larval krill Euphausia superba in autumn and winter in the Lazarev Sea, Antarctica. Limnol Oceanogr 54:1595-1614

Meyer B, Auerswald L, Siegel V, Spahić S, Pape C, Fach B, Teschke M, Lopata A, Fuentes V (2010) Seasonal variation in body composition, metabolic activity, feeding, and growth of adult krill Euphausia superba in the Lazarev Sea. Mar Ecol Prog Ser 398:118

Morris DJ, Priddle J (1984) Observations on the feeding and moulting of the Antarctic Krill, Euphausia superba Dana, in winter. $\mathrm{Br}$ Antarct Surv Bull 65:57-63

Nicol S, Stolp M, Cochran T, Geijsel T, Marshall J (1992) Growth and shrinkage of Antarctic krill, Euphausia superba, from the Indian Ocean sector of the Southern Ocean during summer. Mar Ecol Prog Ser 89:175-181

Nicol S, Virtue P, King R, Davenport SR, McGaffin AF, Nichols P (2004) Condition of Euphausia crystallorophias off East Antarctica in winter in comparison to other seasons. Deep-Sea Research II 51:2215-2224

Nicol S, Foster J, Kawaguchi S (2011) The fishery for Antarctic krillrecent developments. Fish Fish. doi:10.1111/j.1467-2979.2011.0 0406.x

Nishino Y, Kawamura A (1994) Winter gut contents of Antarctic krill (Euphausia superba Dana) collected in the South Georgia area. Proc NIPR Symp Polar Biol 7:82-90

Nordhausen W (1994) Winter abundance and distribution of Euphausia superba and E. cristallorophias, and Thysanoessa macrura in Gerlache Strait and Crystal Sound, Antarctica. Mar Ecol Prog Ser 109:131-142

O'Brien DP (1987) Direct observations of the behaviour of Euphausia superba and Euphausia cristallorophias (Crustacea: Euphausiacea) under pack ice during the Antarctic spring of 1985. J Crust Biol 7:437-448

O’Brien C, Virtue P, Kawaguchi S, Nichols PD (2010) Aspects of krill growth and condition during late winter-early spring off East Antarctica $\left(110-130^{\circ}\right.$ E). Deep-Sea Res II. doi:10.1016/j.dsr2.2010.11.001

Pakhomov EA, Atkinson A, Meyer B, Oettl B, Bathmann U (2004) Daily rations and growth of larval krill Euphausia superba in the Eastern Bellingshausen Sea during austral autumn. Deep-Sea Research II 51:2185-2198

Pape C, Teschke M, Meyer B (2008) Melatonin and its possible role in mediating seasonal metabolic changes of Antarctic Krill, Euphausia superba. Comp Bioch Physiol A 149:426-434

Parkinson CL (2004) Southern Ocean sea ice and its wider linkages: insights revealed from models and observations. Ant Science 16:387-400

Quetin LB, Ross RM (1991) Behavioural and physiological characteristics of the Antarctic krill, Euphausia superba. Amer Zool 31:49-63

Quetin LB, Ross RM (2001) Environmental variability and its impact on the reproductive cycle of Antarctic krill. American Zoologist 41:74-89

Quetin LB, Ross RM (2003) Episodic recruitment in Antarctic krill Euphausia superba in the Palmer LTER study region. Mar Ecol Prog Ser 259:185-200 
Quetin LB, Ross RM (2009) Life under Antarctic pack ice: a krill perspective. In: Krupnik I, Lang MA, Miller ES (eds) Smithonian at the poles, contribution to international polar year science, pp 285-298

Quetin LB, Ross RM, Clarke A (1994) Krill energetics: seasonal and environmental aspects of the physiology of Euphausia superba. In: El-Sayed SZ (ed) Southern Ocean ecology: the BIOMASS perspective. University Press, Cambridge, pp 165-184

Quetin LB, Ross RM, Frazer TK, Habermann KL (1996) Factors affecting distribution and abundance of zooplankton, with an emphasis on Antarctic krill, Euphausia superba. Ant Res Ser 70:357-371

Quetin LB, Ross RM, Frazer TK, Amsler MO, Wyatt-Evens C, Oakes SA (2003) Growth of larval krill, Euphausia superba, in fall and winter west of the Antarctic Peninsula. Mar Biol 143:833-843

Quetin LB, Ross RM, Fritsen CH, Vernet M (2007) Ecological responses of Antarctic krill to environmental variability: can we predict the future? Ant Science 19:253-266

Ross RM, Quetin LB (1986) How productive are Antarctic krill. Bioscience 36:264-269

Ross RM, Quetin LB (1989) Energetic cost to develop to the first feeding stage of Euphausia superba and the effects of delays in food availability. J Exp Mar Biol Ecol 133:103-127

Ross RM, Quetin LB (1991) Ecological physiology of larval euphausiids, Euphausia superba (Euphausiaceae). Mem Qld Mus 31:321333

Ross RM, Quetin LB (2000) Reproduction in Euphausiacea. In: Everson I (ed) Krill biology. ecology and fisheries. Blackwell, Cambridge, pp 150-181

Ross RM, Quetin LB, Newberger T, Oakes SA (2004) Growth and behaviour of larval krill (Euphausia superba) under the ice in late winter 2001 west of the Antarctic Peninsula. Deep-Sea Res II 51:2169-2184

Ross RM, Quetin LB, Martinson DG, Iannuzzi RA, Stammerjohn SE, Smith RC (2008) Palmer LTER: Patterns of distribution of five dominant zooplankton species in the epipelagic zone west of the Antarctic Peninsula, 1993-2004. Deep-Sea Res II 55:2086-2105

Salonen K, Sarvala J, Hakala I, Viljanen M-L (1976) The relation of energy and organic carbon in aquatic invertebrates. Limnol Oceanogr 21:724-730

Schmidt K, Atkinson A, Steigenberger S, Fielding S, Lindsay MCM, Pond DW, Tarling GA, Klevjer TA, Allen CS, Nicol S, Achterberg EP (2011a) Seabed foraging by Antarctic krill: implications for stock assessment, bentho-pelagic coupling and the vertical transfer of iron. Limnol Oceanogr 56:1411-1428

Schmidt K, Atkinson A, Venables H, Pond DW (2011b) Early spawning of Antarctic krill in the Scotia Sea is fuelled by 'superfluous' feeding on non-ice associated phytoplankton blooms. Deep-Sea Res II. doi:10.1016/jdsr2.2011.05.002

Schnack-Schiel SB, Hagen W, Mizdalski E (1998) Seasonal carbon distribution of copepods in the eastern Weddell Sea, Antarctica. J Mar Systems 17:205-311

Schnack-Schiel SB, Dieckmann GS, Gradinger R, Melnikov LA, Spindler N, Thomas ND (2001) Meiofauna in sea ice of the Weddell Sea (Antarctica). Polar Biol 24:724-728

Siegel V (1986) Structure and composition of the Anttarctic krill stock in the Bransfield Strait (Antarctic Peninsula) during the second international BIOMASS experiment (SIBEX). Archiv für Fischreiwissenschaft 37:51-72

Siegel V (1987) Age and growth of Antarctic Euphausiaceae (Crustacea) under natural conditions. Mar Biol 96:483-495

Siegel V (1988) A concept of seasonal variation of krill (Euphausia superb) distribution and abundance west of the Antarctic Peninsula. In: Sarhage D (ed) Antarctic Ocean and Resources Variability. Springer, Berlin, pp 219-230
Siegel V (1989) Winter and spring distribution and status of the krill stock in Antarctic Peninsula waters. Archiv Für Fischereiwissenschaft 39:45-72

Siegel V (2000) Krill (Euphausiacea) life history and aspects of population dynamics. Canad J Fish Aquat Sci 57:130-150

Siegel V (2005) Distribution and population dynamics of Euphausia superba: summary of recent findings. Polar Biol 29:1-22

Siegel V, Loeb V (1995) Recruitment of Antarctic krill Euphausia superba and possible causes for its variability. Mar Ecol Prog Ser 123:45-56

Siegel V, Kawaguchi S, Ward P, Litvinov F, Sushin V, Loeb V, Watkins J (2004) Krill demography and large-scale distribution in the southwest Atlantic during January/February 2000. Deep-Sea Res II 51:1253-1257

Smetacek V, Nicol S (2005) Polar ocean ecosystems in a changing world. Nature 437:362-368

Smetacek V, Scharek R, Nöthig E-M (1990) Seasonal and regional variation in the pelagial and its relationship to the life history cycle of krill. In: Kerry KR, Hempel G (eds) Antarctic Ecosystems, Ecological Change and Conservation. Springer, Berlin, Heidelberg, pp 103-114

Smith RC, Fraser WR, Stammerjohn SE (2003) Climate variability and ecological response of the marine ecosystem in the Western Atarctic Peninsula (WAP) region. In: Greenland D, Goodin DG, Smith RC (eds) Climate variability and ecosystem response at Long-Term Ecological Research sites. Oxford University Press, New York, pp 158-173

Smith RC, Martinson DG, Stammerjohn SE, Iannuzzi RA, Ireson K (2008) Bellingshausen and western Antarctic Peninsula region: Pigment biomass and sea-ice spatial/temporal distributions and interannual variability. Deep-Sea Res II 55:1949-1963

Spiridonov VA (1992) Distribution and biological properties of the Antarctic krill Euphausia superba Dana during winter Weddell Gyre study (WWGS) 1989. Proc NIPR Symp Polar Biol 5:55-64

Spiridonov VA, Gruzov EN, Pushkin AF (1985) Investigations of schools of Antarctic Euphausia superba (Crustacea, Euphausiacea) under the ice. Zoologichesky Zhurnal 11:1655-1660

Stammerjohn SE, Martinson DG, Smith RC, Iannuzzi RA (2008) Sea ice in the western Antarctic Peninsula region: Spatio-temporal variability from ecological and climate change perspectives. Deep-Sea Res II 55:2041-2058

Stepnik R (1982) All-year population studies of Euphausiaceae (Crustacea) in the Admiralty Bay (King George Island, South Shetland Island Antarctica). Pol Polar Res 3:49-68

Taki K, Hayashi T, Naganobu M (2005) Characteristics of seasonal variation in diurnal vertical migration and aggregation of Antarctic krill (Euphausia superba) in the Scotia Sea, using Japanese fishery data. CCAMLR Science 12:163-172

Tanimura A, Fukuchi M, Hoshiai T (1986) Seasonal changes in the abundance and species composition of copepods in the ice-covered sea near Syowa Station, Antarctica. Memoirs National Institute of Polar Research, Special Issue 40:212-220

Tanimura A, Hattori H, Miyamoto Y, Hoshiai T, Fukuchi M (2008) Diel changes in vertical distribution of Oithona similis (Cyclopoida) and Oncaea curvata (Poecilostomatoida) under sea ice in mid-summer near Syowa Station, Antarctica. Polar Biol 31:561-567

Teschke M, Kawaguchi S, Meyer B (2007) Simulated light regimes affect feeding and metabolism of Antarctic krill, Euphausia superba. Limnol Oceanogr 52:1046-1054

Teschke M, Kawaguchi S, Meyer B (2008) Effects of simulated light regimes on maturity and body composition of Antarctic krill, Euphausia superba. Mar Biol 154:315-324

Teschke M, Wendt S, Kawaguchi S, Kramer A, Meyer B (2011) A circardian clock in Antarctic krill. PLoS ONE 6(10):e26090. doi:10.1371/journal.pone. 0026090 
Tessmar-Raible K, Raible F, Arboleda E (2011) Another place, another timer: marine species and the rhythms of life. Bioessays 33:165-172

Thomas DN, Dieckmann G (2003) Sea Ice, an introduction to its physics, chemistry, biology and geology. Blackwell, London

Thomas PG, Ikeda I (1987) Sexual regression, shrinkage, re-maturation and growth of spent female Euphausia superba in the laboratory. Mar Biol 95:357-363

Thorpe SE, Murphy EJ, Watkins JL (2007) Circumpolar connections between Antarctic krill (Euphausia superba Dana) populations: Investigating the roles of ocean and sea ice transport. Deep-Sea Res I 54:792-810

Tilden AR, Alt J, Brummer K, Groth R, Herwig K, Wilson A, Wilson $\mathrm{S}$ (2001) Influence of photoperiod on $N$-acetyltransferase activity and melatonin in the fiddler crab Uca pugilator. Ge Comp Endocrinol 122:233-237

Töbe K, Meyer B, Fuentes V (2010) Detection of zooplankton items in the stomach and gut content of larval Krill, Euphausia superba, using a molecular biology approach. Polar Biol 33:407-414

Torres JJ, Aarset AV, Donnelly J, Hopkins TL, Lancraft TM, Ainley DG (1994a) Metabolism of Antarctic micronektonic Crustacea as a function of depth of occurrence and season. Mar Ecol Prog Ser 113:207-219

Torres JJ, Aarset AV, Donnelly J, Hopkins TL, Lancraft TM, Ainley DG (1994b) Proximate composition and overwintering strategies of Antarctic micronektonic Crustacea. Mar Ecol Prog Ser 113:221-232

Tovar-Sanchez A, Duarte CM, Hernández-León S, Sañudo-Wilhemy SA (2007) Krill as a central node for iron cycling in the Southern Ocean. Geophys Res Lett 34:L11601. doi:10.1029/2006GL 029096

Trivelpiece WZ, Hinke JT, Miller AK, Reiss CS, Trivelpiece SG, Watters GM (2011) Variability in krill biomass links harvesting and climate warming to penguin population changes in Antarctica. PNAS 108:7625-7628

Yoshida T, Kawaguchi S, Meyer B, Virtue P, Penscho J, Nash G (2009) Structural changes in the digestive glands of larval Antarctic krill (Euphausia superba) during starvation. Polar Biol 32:503-507

Zhou M, Nordhausen W, Huntley M (1994) ADCP measurements of the distribution and abundance of euphausiids near the Antarctic Peninsula in winter. Deep-Sea Res I 41:1425-1445 